\title{
Üniversite Öğrencilerinin Bir Sosyalleșme Alanı Olarak Sosyal Medya Hakkındaki Görüşleri
}

\author{
University Students' Views on Social Media \\ As a Socialization Area
}

\begin{abstract}
Mehmet Tahir KARABOĞA*
Öz: İnternet ortamında yaygınlaşarak önem kazanan sosyal medya ağları toplumsal yaşama etki edecek düzeyde gelişim göstermiştir. Bu sosyal ağlar bireyler üzerinde farklı etkiler gösterirken geleneksel sosyal yaşamın dışında bir değişimi ve sosyalleşme biçimini beraberinde getirmektedir. İnternet uygulamaları içerisinde özellikle sosyal medya, önemli bir sosyalleşme aracıdır. Toplumsallaşma sürecinin başat noktalarından olan gençlik dönemi de bu bağlamda incelenmesi gereken önemli bir aşamayı oluşturmaktadır. Bu anlamda çalışmanın ana temasını sosyal medya ortamlarının üniversite öğrencilerinin sosyalleşme şekillerinde yarattı̆̆ 1 değişim ve dönüşüm oluşturmaktadır. $\mathrm{Bu}$ araştırma, üniversite öğrencilerinin bir sosyalleşme alanı olarak sosyal medya hakkındaki görüşlerini; sosyal medya ortamlarındaki kültürel değerler, bilginin niteliği, ilişki biçimleri, ifade ş̧ekli, kültürel özellikler, davranış özellikleri çerçevesinde incelemeyi amaçlamaktadır. Araştırmanın verileri, 2018-2019 eğitim öğretim yılı güz döneminin başında Mersin üniversitesinde (4 fakülte, 1 Yüksekokul ve 1 Meslek Yüksek Okul) okuyan 394 öğrencinden alınan veriler doğrultusunda toplanmıştır. Araştırmanın verileri araştırmacı tarafından geliş̧iren bir anket aracılığı ile toplanmıştır. Veriler önce kodlanmış ve SPSS paket programına yüklenmiştir. Araştırma alt problemleri izlenerek yürütülen frekans ve yüzdelik betimleyici istatistiksel teknikleri ile araştırmaya katılan üniversite öğrencilerinin bir sosyalleşme alanı olarak sosyal medya ağları hakkında görüşleri incelenmiştir. Araştırmanın bulguları; üniversite öğrencilerinin sosyal medya ortamlarında diğer insanların dürüst ve samimi davranmadıklarını, gerçek dostluk ilişkileri yaşamadıklarını düşünmektedir. Üniversite öğrencileri sosyal medya ortamlardaki bilginin çoğunlukla bilimsel nitelikli bilgiler olmadığını, magazinsel ve dedikoduya dayalı bir bilgi olduğunu, sosyal medyadaki ilişki biçimlerinin gerçek aile ve arkadaşlık ilişkisinin yerini tutmadığını ifade etmektedirler.

Anahtar Kelimeler: Sosyal medya, sosyalleşme, sosyal medyada sosyalleşme
\end{abstract}

\begin{abstract}
Social media networks, which gained importance by becoming widespread in internet environment, have developed in a level that will affect social life. While these social networks have different effects on individuals, they bring about a different form of socialization apart from the traditional social life. Social media, especially in internet applications, is an important socialization tool. The youth period, which is one of the main points of the socialization process, constitutes an important stage to be examined in this context. In this sense, the main theme of this study is the transformation created by social media environments in the socialization process of university students. The aim of this research is to examine university students' opinions on the social media as a socialization area in terms of cultural values, nature of the information, the forms of relationship, way of expression, cultural characteristics and behavioral characteristics in the social media environment. The data were collected from 394 students who studied at Mersin University (4 faculties, 1 college and 1 vocational college) at the beginning of the 2018-2019 academic year fall semester. The data of the study were collected by a questionnaire which was developed by the researcher. The data was first encoded and loaded into the SPSS package program. The frequency and percentage descriptive statistical techniques were carried out following the research sub-problems and the opinions of the university students participating in the study on social media networks as a socialization area were examined. According to the findings of the research, university students think that other people do not act honestly and sincerely in social media environments and they do not have real friendship relations. University students state that information in
\end{abstract}

*Dr. Öğretim Üyesi, Mersin Üniversitesi, Eğitim Fakültesi, Mersin-Türkiye, ORCiD. 0000-0003-0795-

7991: e-posta: tahirkaraboga@mersin.edu.tr 
social media is usually not scientific knowledge, it is an information based on magazines and gossip, and that the forms of relationship in social media do not replace the real family and friendship relationship.

\section{Giriş}

Toplumu hem nesnel, hem de sosyo-kültürel anlamda kuşatma altına alan dijital iletişim teknolojileri, gündelik hayatın her alanına sızarak bireylerin ilişiklerine, yaşam tarzlarına ve alışkanlıklarına etki ederek onları değiştirmekte ve dönüştürmektedir. Bireylerin; iletişim kurma ve sosyalleşme biçimleri, sosyalleşme mekânları, yaşam tarzları ve ilişkileri farklı bir hal alarak hızlı bir evrim sürecinden geçmektedir.

Günümüzde kitle iletişim araçları içerisinde en önemli ve giderek yaygınlık kazanan sosyal medya, toplumsal hayatın en önemli konularının başına yerleşmiştir. İnsanların bilgi, belge, haber paylaşımında bulunduğu, tüm dünyada yaygınlaşan dijital platformlarının önemi gün geçtikçe daha da arttırmaktadır. Sosyal medya bireysel anlamda; kişilerin kendilerini ifade edebilme, kendisiyle ortak yönleri olan insanlarla yakın ilişkiler kurma, dünyada olup bitenler hakkında hızlı bilgi sahibi olma gibi kolaylıklar sağlarken; toplumsal anlamda bireylerin aile, mahalle, komşuluk, arkadaşlık ilişkilerinde bir zayıflamayı beraberinde getirmektedir. İlişkilerdeki bu dönüşüm ve zayıflama geleneksel kültür kodlarını farklılaştırarak toplumsal alanda farklı küresel sanal kültürel değerlerin ortaya çıkmasına zemin hazırlamaktadır.

Yeni iletişim teknolojilerinin bireylerin yaşam biçimlerinde, alışkanlıklarında, kültürlerinde, iş yaşamlarında, eğitim sistemlerinde önemli dönüşümler meydana getirdiği görülmektedir Modern insanın, yüz yüze iletişim kurmak yerine, sosyal medya ve iletişim teknolojileriyle aracılanmış bir iletişim biçimini tercih etmesi, farklı sorunları da beraberinde getirmektedir. Yaşadığımız dijital çağda, zaman, mekân ve insan ilişkilerinin dönüşüme uğradığı görülmektedir. Dijital dünya ile kastedilen, sosyal ağlar, taşınabilir iletişim araçları ile birlikte insanların hayatını tamamen kuşatmıştır. Bu noktadan hareketle, sosyal ağlar, bireylerin sosyal ve kültürel yaşamlarında önemli dönüşümler yaratmaktadır (Karagülle ve Çaycı, 2014).

İletişim teknolojilerinin yaygınlaşması ile kültürlenme biçimleri değişmiş, gerçek yaşamdaki sosyalleşme biçimleri ve mekânları, yerini sanal ortamlara bırakmıştır. Bu yeni ortamlar insanlara iletişim kurma konusunda pratiklik, kolaylık sağlaması açısından avantajlara getirmesine rağmen; bünyesinde bireylerin gerçek hayata yabancılaşmasına, yalnızlaşmasına, samimiyet ve dürüstlükten uzaklaşmasına, gözetleme ve gözetlenme kültürünü içselleştirmesine, gerçek ile sanal olanın bir birine karıştırmalarına sebebiyet verebilmektedir. Bu sürecin içinde en çok yer alan kesimlerin başında ise üniversite öğrencileri olmaktadır. Sosyal medya paylaşım ağları üniversite öğrencileri tarafından yoğun bir şekilde kullanılan bir alandır. Üniversite öğrencileri, sosyal medya kullanıcılarının önde gelen kesimlerin başında gelmektedir. Öğrencilerin oyun oynama, eğlenme, ders çalışma, iletişim kurma, yemek yeme gibi en temel davranışları dahi gelişen teknoloji, internet ve sosyal medya ile değişim göstermiştir.

Bugün dünyada 3 milyara yakın insanın, Türkiye'de ise yaklaşık 51 milyon kişinin sosyal medyayı aktif olarak kullanıyor olması (Sabah, 2018), sosyal medyanın ne derecede yaygın ve önemli hale geldiğini bize göstermektedir. $\mathrm{Bu}$ anlamda bu alanda olup biten iletişimin, etkileşimin ve sosyalleşmenin ne şekilde cereyan ettiğini bilmek, toplumsal alanda olup bitenleri anlamak açısından önemli hale gelmektedir.

İnternet ortamında yaygınlaşarak önem kazanan sosyal medya ağları toplumsal yaşama etki edecek düzeyde gelişim göstermiştir. Bu sosyal ağlar bireyler üzerinde farklı etkiler gösterirken yüz yüze sosyal yaşamın dışında bir değişimi ve sosyalleşme biçimini beraberinde getirmektedir. İnternet uygulamaları içerisinde özellikle sosyal medya, önemli bir sosyalleşme aracıdır. Toplumsallaşma sürecinin kritik aşamalarında olan gençlik dönemi de bu bağlamda incelenmesi gereken önemli bir aşamayı oluşturmaktadır. Bu anlamda çalışmanın ana temasını sosyal medya ortamlarının, üniversite öğrencilerinin sosyalleşme şekillerinde yarattığı değişim ve dönüşüm oluşturmaktadır. Sosyal medya ortamlarındaki sosyalleşme kavramı; kültürel değerler, bilginin niteliği, ilişki biçimleri, kişilerin kendini ifade etme şekli, kültürel özellikleri, kişilerin davranış özellikleri çerçevesinde ele alınmıştır. 


\section{Sosyal Medya}

Sosyal medya; kişilerin internet kullanarak birbirileriyle bilgi, görüş, yazıll, görsel veya işitsel materyal paylaşmaya olanak sağlayan, kişiler arasındaki karşıllklı etkileşime imkân tanıyan, herkesin kendi kişisel profilini ve iletişim kurmak istediği arkadaş listesini oluşturma şansı veren araçlar ve web tabanlı ortamlar olarak tanımlanabilir. Günümüzde en popüler olarak bilinen sosyal medya plarformları şu şekilde sıralamk mümkündür "Facebook, Google Plus, Foursquare, Myspace. Bloglar: Blogger.com, Wordpress Mikrobloglar: Twitter, Tumblr Profesyonel A $\breve{g}$ Siteleri: LinkedIn, Fotoğraf Paylaşım Siteleri: Flicker, PhotoBucket, İnstagram, Flickr, Pinterest Video Paylaşım Siteleri: Youtube, Daily Motion, Vimeo, Vidivodo Vikiler: Vikipedi." (Uzundumlu, 2015, s. 26). Bunlar içerisinde en yaygın sosyal medya ağlarını Facebook, Instagram, Twitter, WhatsApp, YouTube gibi platformlardır. Genel olarak sosyal ağların temel özellikleri şu şekilde belirlenmiştir: "Kişisel profil sunması, bağlantı kurulabilmesi, gruplara katılabilme, bağlantılarla iletişim kurabilme, paylaşım, fikir beyan edebilme, bilgi erişimi ve kullanıcılarını uzun süreli olarak online tutabilme. Bu özellikler sosyal paylaşım ağlarının genel karakteristik yapısını ortaya koymaktadır" (Göker, Demir ve Doğan, 2010, s. 188). Sosyal medya ortamlarında kullanıcılar; bilgi, fotoğraf, video paylaşımı, film izleme, müzik dinleme, sohbet etme, yer bildirimi yapma, iletişim kurma vb. amaçlar için kullanabilmektedirler.

Sosyal medyaya yönelik olumlu bakış açılarında; bireyin dış dünyaya kıyasla bu ortamda kendisini daha güvenli ve mutlu hissettiği, sosyal medyanın bireyin sosyalleşmesine, yeni arkadaşlıklar, dostluklar kurulmasında vesile olduğu, bireyin yeni bilgi ve beceriler kazandıdığı, bireyin kendisini daha rahat ve özgürce ifade edip iletişim kurabilmesine yardımcı olduğu vurguları ön plana çıkarılmaktadır. "Günümüzde toplumsal ilişkilerin en yoğun şekilde

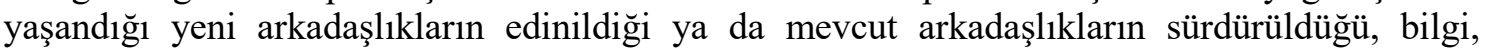
beceri, beğeni gibi çeşitli paylaşımların gerçekleştiği ortam/iletişim aracı sosyal ağ siteleridir. Sosyal paylaşım ağlarında paylaşılan fotoğraf, video, müzik gibi unsurlar ise kullanıcılarının kimlik üretimlerine ve ürettikleri kimlikleri duyurmalarına yöneliktir" (Toprak ve diğerleri, 2009, s. 108). Katıldığı toplumsal paylaşım ağları ile birlikte bireylerin iletişim biç̧imi değişmiş, karşılıklı paylaşım ve etkileşim unsurları yeni bir boyut kazanmıştır. Toplumsal paylaşım ağlarında bireyler, bir topluluğa aidiyet duygusunu yeniden inşa etmekte boş vakitlerini değerlendirme ve iletişim kurma gibi amaçlarını buralarda gerçekleştirmektedir. Bunun yanında kullanıcılar toplumsal paylaşım ağlarını bilgi erişimi ve paylaşma aracı olarak da kullanmaktadır (Güçdemir, 2010, s.55).

Sosyal medyanın özelliklerine baktığımızda bireylerin oluşturdukları kişisel sayfalar ile kendi kimliklerini oluşturma, diğer kişilerle etkin bir iletişimde bulunma, kendini daha rahat ifade etme, çift yönlü iletişim gibi avantajlar sağlayabilmektedir. Sosyal medya uygulamaları aracıllğıyla bireyler kendi kişisel sayfalarını oluşturabilmekte ve buna dayalı olarak iletişimde bulunabilmekte, diğerleriyle etkileşim kurabilmektedir. Hazar'a (2011) göre, sosyal medyanın en önemli özelliği kişilerin kendilerini diğer insanlara görünür açık bir biçimde internet üzerinden kendini ifade edebilmesidir. Gürsakal (2009), sosyal medyanın özelliklerini beș ana başlık altında toplamaktadır. Bunlar; katılım, açıklık, karşılıklı konuşma, topluluk ve bağlantısallık şeklinde sıralamaktadır. "Sosyal medya, iletişim kurulan kişilerin geribildirimde bulunmasını ve gerekli katkılar göstermesini kolaylaştırmaktadır. Sosyal medya bireylere, çift yönlü iletişim, rahatlık ve zamanında geribildirim imkânı sunmaktadır. Sosyal medya toplulukların ilgili konu veya kişiler üzerinde hızla oluşmasına ve buna bağlı olarak etkin bir şekilde iletişim kurulmasına izin vermektedir” (Tutgun Ünal, 2015, s. 56-57).

Sosyal medya, kimlik kavramının değişmesine ve kişilerin kimliklerini istedikleri şekilde sanal ortamda inşa etmelerine olanak sunmuştur. Sınırlar, kimlikler, fiziksel özellikler, yaş, cinsiyet gibi kavramlar burada yeniden ve kişinin istediği şekilde şekillendirilebilmektedir. Kişilerin sosyal medya üzerinde birden fazla kimliği olabilmektedir. Sosyal medyada görünen kişilerin kimliklerinden tam olarak emin olmak ve onlarla sağliklı iletişim kurabilmek mümkün değildir. İnsanların her istediği kimliğe bürünebildiği, bu konuda bir güvenlik sağlamanın pek mümkün olmadığı bir alan olan sosyal medya, kimlik konusunun önemini ortaya çıkarmıştır. 
Günümüzde her olay, her olgu sanal alemde paylaş1labilmektedir. İletişim kurma şekli, bilgi edinme, bilgi paylaşma şekli geleneksel dönemden oldukça farklı bir hal almıştır. Postmodern dönemde insanlar internet ve sosyal medya aracılığı ile paylaşım yapabilmekte, bilgilerini, deneyimlerini, fotoğraflarını, kendi hayatları ile ilgili her detayı sevdikleri ile sosyal medya aracılığg ile paylaşmaktadır ( Kök, 2013, s. 52).

Sosyal medya kullanımı bireyler açısından bazı avantajlar sağlamakla birlikte beraberinde bazı riskleri de barındırmaktadır. Bireyin diğer kişilerin fikir ve düşüncelerin empozesine, yönlendirilmesine açık halde bulunması, sanal arkadaşlıkların gerçek arkadaşlıkların yerini tam olarak tutmaması ve bireyin kendisini daha da yalnız hissetmesi, gerçek hayatta asosyalleşmesi ve buna bağlı olarak yaşam tarzının değişmesi gibi faktörler ön plana çıkabilmektedir. Sosyal medyaya yöneltilen diğer eleştirileri de şu şekilde sıralamak mümkündür: Bireyde psikolojik (nispetizm, narsizm, hazc1lı, yalnızlık, stres) sorunların artması, empati kaybı, duyarsızlaşma, yalan beyanlarda bulunma, hafızada, bellekte zayıflık, kitap okuma kültürünün gerilemesi, hareketsiz ve kapalı mekanlarda bir yaşama mahkum olunması, aile ve mahalle ilişiklerin zayıflama, gerçeklikten sanala bir kayma vb.

Uluç ve Yarcı (2017), dijital iletişimle birlikte insanlık tarihindeki en büyük değişimlerden birinin yaşandığını, özellikle başkalarının ne düşündüğünü, hissettiğini öğrendiğimiz sosyal medyanın, davranışlarımızı etkileyebilen ve/veya şekillendirebilen çok güçlü bir araç olduğunu belirtmektedirler. Baym ve Boyd'a (2012) göre sosyal medya varlık ve yokluk, zaman ve mekân, kontrol ve özgürlük, bireysel ve kitlesel iletişim, özel ve kamusal, sanal ve gerçek arasındaki sınırları bulanıklaştırmaktadır.

Aktaş (2017), sosyal medya kullanımının zaman içerisinde beraberinde getireceği sorunları bireyin sosyal ilişkilerinde yaratacağı sorunlara ve bireyin yalnızlaşması boyutuna dikkat çekmektedir. Aktaş, geleneksel iletişimden sosyal ağ iletişimine geçişle birlikte sosyal medyanın, bireyleri, zamanla gerçek ilişkilerinden uzaklaştırarak sanal arkadaşlıklar ve sanal iletişimin içine çektiğini ve uzun vadede bu durumun kişilerde yalnızlaşmayı arttırabileceğine vurgu yapmaktadır. Diğer bir risk boyutu ise bireyin her türlü kültürel tercihinin yönlendirilmesi tehlikesidir. "Popüler olan kelimelerle konuşmasın1, popüler olan kiyafetlerle, popüler mekânlara gitmesini sağlayabileceği gibi, kendi kontrolünde olan sohbetleri de oluşturabilme imkânını sunmaktadır. Konuşmaları önceden hazırlayabilmeyi, istediği anda yanıt vererek hazırlanmış, düzenlenmiş iletişim ve etkileşimleri ortaya koyabilmektedir” (Aktaş, 2017, s. 1). Tutgun Ünal ise, sosyal medya kullanımının barındırdığı riskleri toplumsal, psikolojik ve fizyolojik problemler üzerinden ele almaktadır. "Bireyler sosyal medya üzerinden birtakım ihtiyaçlarını karşılayarak tatmin olma yolunda ilerlerken, diğer taraftan pek çok tehlikeye de açık konumda bulunmaktadır. Aşırı sosyal medya kullanımından dolayı bağımlılık gibi psikolojik problemler, uyku bozuklukları ve el, baş, sırt gibi birtakım fiziksel ağrıların ortaya çıktığı belirtilmektedir" (Tutgun Ünal, 2015, s. 75).

Bekiroğlu ve Hülür, sosyal medyanın gerçeklik, sanallık ve kurgusallık boyutlarına vurgu yapmaktadır. "İnternet ve onun ürünü olan sosyal paylaşım ağlarında sunulan gerçeklik, kurgulanmış bir gerçekliktir. Yani aynı anda iki farklı gerçeklik algısı söz konusudur. Normal insanların gündelik yaşamda algıladıkları gerçeklikle her ne kadar paralel gibi görünse de, sosyal medyanın kurgusal dünyası içinde birey, belli bir sisteme uyarlanmış, belli sistematikten geçen ve aracılandırılmış bir gerçeklikle yüz yüzedir” (Bekiroğlu ve Hülür, 2016, s. 157).

Timisi (2005), sosyal medyada mekânın, bedenin ve dilin özellikleri konusunda değerlendirmelerde bulunmaktadır. "Dilin özellikleri Sosyal paylaşım ağlarında özne, dilin sınırları içinde tezahür eder. Dilin sabitlemediği özne, gerçek değildir ya da yoktur. Bedenin sınırlaması ortadan kalkmıştır. Beden artık görünenin temsili değildir. Beden, dilin kurduğu bedendir. Cinsiyet, ırk, renk dilin sınırları içinde inşâ edilir. Siber-uzam, dilde açığa çıkan öznenin sınırlanmamış bir toplumsal alanıdır. Sosyal paylaşım ağlarında kişinin varlı̆̆ 1 "beden ve mekândan arınmış ve yalnızca kelimelere dönüşmüş bir biçimde vücut bulmaktadır. Bu anlamda internet hayal edilmiş ve hayali bir mekân olarak tanımlanabilir ancak aynı zamanda söylemsel etkileşimlerden oluşan ve hayal gücümüzü yapılandıran bir mekândır" (Timisi, 2005, s. 97). Armağan'a (2013) göre, "sanal ortamdaki iletişim örüntüsü, gerçek yaşamdan farklı 
olarak metinler üzerinden kurulmakta ve anlamlandırılmaktadır. Farklı bir ifade ile, bireyin gerçek imajını sunarken kullandığı jest, mimik, ses tonu ve artifakslar yerini; sembol, simge ve göstergelerden oluşan dile bırakmaktadır. Gençler dil üzerinden ve dil aracılığı ile kendini sunmaktadir (s. 81).

Özdemir'e (2015) göre sosyal ağlarda neyin gerçek neyin sahte olduğu hep bir soru işaretidir. Özellikle bireyin başkaları tarafından beğenilme ve takdir edilme isteği gerçek kimliklerin ortaya koyulmasında bir engeldir (s. 127). Özdemir, kişilerin sosyal ağlarda oluşturduğu profilde her zaman kendilerini olduğu gibi sunmadıklarını, kişilerin kendinde sevdiği özellikleri ön plana çıkarttığını sevmedikleri özelliklerini ise gizleme eğiliminde olduklarını belirtir. Uzundumlu (2015), artan internet kullanımıyla birlikte zaman ve mekân kavramının, yüz yüze ilişkilerin ortadan kaybolduğunu, sanal kimliklerin ön plana çıktığını belirtmektedir. Uzundumlu'ya göre, “insanlar, yalnızlık duygusuyla sosyal ağlarda başka bireyler tarafından beğenilme ve ilgi görme arzusuyla farklı kimliklere bürünmekte ve kendi kimliklerinden sıyrılarak, yeni bir kimlik oluşturmaktadırlar. Sosyal medyada sahte kimliklere sahip pek çok kişinin yer aldığını belirten Uzundumlu, bu durumun gerçek hayatı olumsuz etkilediğini ifade etmektedir. İnsanlar sosyal medyada onaylanmak, kendini göstermek, takdir görmek, beğenilmek istemektedirler. Bu durumda da gerçek kimliklerin yansıtılmalarını engellemektedir" (s. 152). Sosyal medya ortamlarında birey kendi hayatını teşhir ederken hem öteki insanları ne yaptıklarına ilişkin gözetlemekte hem de kendisi özel hayatını bütün çıplaklığıyla mahremiyetini gözler önüne sermektedir. Sosyal medya ortamlarında yaşam tarzı ve gündelik yaşama ait anların rutin işlerin yoğun paylaşımı kamusal ve özel alan ayırımını silikleştirerek mahremiyeti ortadan kaldırmaktadır. Birey popülaritesini artırmak, kendini ortaya koymak, onaylatmak için imaj ve görsellere yoğun bir şekilde başvurmaktadır.

\section{Sosyalleșme}

Sosyalleşmeyi, insanı sosyal sistemin üyesi haline getiren kişinin grup normlarına uymasını saplayan bir öğrenme süreci olarak tanımlamak mümkündür. Sosyalleşme; insanların doğumlarından ölümlerine değin hem bireysel, hem de toplumsal bir varlık olarak geliştikleri süreçtir. Sosyalleşme ile kişi içinde bulunduğu toplumun kurallarını, gelenek ve göreneklerini, alışkanlıklarını ve kültürünü öğrenir.

Sosyalleşme; toplumdaki mevcut ya da beklenen rolleri yerine getirmek için gerekli olan becerilerin, bilgilerin, değerlerin, eğilimlerin ve benlik algılarının özümsenmesi ve gelişimi olarak tanımlanmaktadır (Kenyon ve McPherson, 1974). Bakıroğlu (2013), sosyalleşmeyi insanın kimliğini oluşturması, toplumun mevcut değer ve normlarının bireylere öğretilme süreci olarak tanımlamaktadır.

Dört temel sosyalleşme aracıdan bahsetmek mümkündür. Bunlar; aile, okul, arkadaş grupları ve kitle iletişim araçlarıdır. Aile, bireyin sosyalleşmesini sağlayan ilk birim olarak çocuğun toplumsal hayata hazırlanmasında önemli bir rol oynar. Bireylerin en önemli sosyalleşme kazanımlarından biri olan dili ve temel davranışları aile kurumunda öğrenirler. Aile kurumundan sonra en önemli ikinci sosyalleşme aracını ise okul kurumu oluşturur. Okul, bireylere birtakım bilgi, beceri, tutum ve değerler kazandırır. Bunun sonucunda da bireylerde gözlenebilen birtakım davranış değişiklikleri meydana gelir. Toplumda yaşayan insanların kişiliğine ve geleceğine okulda biçim kazandırılmakta; okul, bireylere ve bireylerden oluşan toplumlara yön vermektedir. Toplumsal yaşayışımız, dolayısıyla toplumsal davranışlarımız, düşüncelerimiz, kişiliğimiz üzerinde okul kurumunun önemli bir etkisi vardır.

Aile ve okul gibi sosyalleşme ortamı sunan önemli sosyalleşme araçlarından biri de arkadaş gruplarıdır. Bireyler daha küçük yaştan itibaren arkadaş gruplarında çatışma, iş birliği, rekabet gibi deneyimleri yaşarlar ve beklentileri, arzuları ve yönelimleri doğrultusunda kendilerini özgürce ifade etmeyi öğrenirler. Bakıroğlu'na göre, sosyalleşme, dinamik ve çok yönlü bir süreçtir. Bu süreç içerisinde medya oldukça etkili bir role sahiptir. Sosyalleşme süreci ikiye ayrılmaktadır. Bunlardan birincisi ailede başlayan ve okula kadar olan dönemi kapsayan birincil sosyalleşme sürecidir; diğeri ise okulla başlayan ve insanın ömrünün sonuna kadar devam eden ikincil sosyalleşmedir (Bakıroğlu, 2013). 
Kitle iletişim araçları olarak nitelendirdiğimiz medya ise, diğer sosyalleşme araçlarından daha farklı bir etkiye ve öneme sahip olarak karşımıza çıkmaktadır. Medya, milyonlarca bireyin bilgi, duygu, düşünce, inanç, tutum ve davranışlarını etkileyen bir güce de sahiptir. Toplumun bütün kesimleri dünyaya ilişkin haberleri, bilgileri çoğunlukla medya aracılığıyla öğrenmektedir. Sosyalleşme, eğlenme, günlük olaylar hakkında haberdar olma, iletişim kurma, arkadaş bulma, oyun oynama, zaman geçirme vb. faaliyetlerin çoğu medya üzerinden gerçekleştirilmektedir. Medyada sunulan dünya gerçeğin kendisi değil, gerçeğin temsil edilmiş dolayımlanmış halidir. Hayali ve kurgulanmış olanın gerçekmiş gibi algılanmasına veya gerçeğin ise kurgu ve hayalmiş gibi düşünülmesine yol açabilmektedir. Yani ekranda görülen gerçeklik bir çeşit illüzyon oluşturabilmektedir. Bu anlamda medya öteki eğitim ve sosyalleşeme araçlarından önemli oranda farklılık göstermektedir.

Medya ortamında bireyin sosyalleştiği en önemli mecralardan biri de sosyal medya denilen kanallardır. Bireyler sosyal medya ortamlarında değerleri, kuralları, kültürü, iletişimi öğrenir. Okul, aile ve arkadaşlık ilişkilerinde birey arkadaşlarla zaman geçirirken yüz yüze konuşurken sosyal medyada bu dolaylı olarak gerçekleşir. Bireyler sosyal medya ortamlarında takip ettikleri ünlü kişileri model alarak rolleri, kuralları, kültürü öğrenebilmekte, farklı bir kimlik edinebilmektedir. Aynı zamanda kişi sosyal medyada giyim tarzlarını, davranış ve konuşma kalıplarını, grubun değerlerini ve kurallarını öğrenebilmektedir. Sosyal medya ortamlarında kişinin katıldığı sosyal gruplar, onun kültürünü, benimsediği değerleri, alışkanlık ve davranış kalıplarını, giyinme biçimini, benliğini, kişiliğini etkileyebilmektedir.

\section{Bir sosyalleşme alanı olarak sosyal medya}

Sosyal medya bireylerin sosyalleştiği ve paylaşımlarda bulunduğu önemli bir sosyal mekânı oluşturur. Çok sayıda insan gündelik yaşamlarında zamanlarını büyük bir bölümünü sanal ortamlarda eğlenerek, paylaşımlarda bulunarak geçirmektedir. Bu durum bireylerin yaşamlarını etkilemekte ve yeni iletişim ve sosyalleşme biçimlerinin ortaya çıkmasına neden olmaktadır. Tutgun Ünal'a (2015) göre günümüzde sosyal ağların kişisel bilgilerin paylaşılması, gruplara katılma, düşüncelerin ifade edilebilmesi ve kullanıcıların aktif tutulması gibi özellikleri dikkate alındığında, sosyal medyanın sosyalleşme süreci üzerinde oldukça etkin rol oynadığı görülmektedir.

Sosyal medya ağlarının bireyin normal hayatta söyleyemediği, ifade edemediği duyguları, düşünceleri ortaya koyma firsatı vermesi, bireyin kendisini daha özgür ve güvende hissetmesi, istediği kişilerle iletişim kurma imkânını vermesi bağlamında olumlu bir açıdan değerlendiren pek çok yaklaşım mevcuttur.

Göker, Demir ve Doğan (2010) sosyal medyayı yeni bir iletişim alanı, farklı bir sosyalleşme mekânı bağlamında ele almaktadır. Onlara göre, "bireyin gündelik yaşamında sosyal etkileşim alanlarının birçoğu, mekânsal sınırları aşarak sanal ortama taşınmıştır. Birey bu alanlarda sosyal çevresinden olsun ya da olmasın birçok kişiyle iletişim ve etkileşim olanağına kavuşurken, sosyalliğin yeni bir şekliyle yüz yüze gelmektedir. Özellikle paylaşıma dayalı bir sosyal ortamın simüle edildiği sosyal paylaşım ağları, bireylerin duygu, düşünce, durum, resim, video, müzik gibi birçok paylaşımla kurulan sosyal etkileşime zemin hazırlayarak sosyalliğe ve sosyalleşmeye dair eylemleri, aslına uygun bir şekilde yeniden kurgulamaktadır" (s. 186).

Baş'a (2015) göre, yeni iletişim teknolojileri bireylere, görülmeyi, tanınmayı, beğenilmeyi, ayırt edilmeyi, işitilmeyi, değer görmeyi, vs. vaat etmektedir. "Bireylerin bu ihtiyaçlarını sanal ortamlarda karşılama isteği beraberinde bireyin çeşitli sosyal kimlikler oluşturmaları için uygun ortam hazırlamaktadır. Çoğu kez sanal bir nitelik taşıyan ve gerçek yaşamda karşılık bulamayan bu kimlikler, bireyin ulaşamadığı, gerçek hayatta olmak isteyip de olamadığı durumları gerçekleştirebilecekleri bir mekân olarak da işlevini sürdürmektedir" (s. 32). Kuşay'a (2003) göre, ergen; gelişim sürecinde kendini bulmaya çalışırken, yaşadığ sorunların üstesinden gelmek için sosyal medyadan da faydalanmaktadır. Sosyalleşmek, merak ve ilgilerine yönelik tatmini sağlamak, sıkıntılarından kurtulmak, boş zamanlarını değerlendirmek, arkadaşları ile olan iletişim süreçlerini güçlendirmek için sosyal medyaya yönelmektedirler. 
Bir sosyal paylaşım ağları sosyal hayatın vazgeçilmez bir parçası haline gelerek sosyalleşme mekânlarını dönüşüme uğratmış; yüz yüze görüşmenin önüne geçerek bireylere, zaman ve mekândan bağımsız bir iletişim şeklini ortaya çıkarmıştır. Sosyal medya ortamlarında bireylerin kendini konuşma dilinden ziyade görsellik ile ifade etme şeklini tercih ettiklerini görüyoruz. Burada kişi kendisi ya da sevdiği kişiler ile ilgili görsel fotoğraflar, videolar ya da müzikler paylaşabilmektedir. Dursun (2016), sözlü kültürden yazılı kültüre, daha sonra görsel kültüre ve en son olarak dijital kültüre geçişle birlikte, bireylerin anlam üretme, paylaşma ve dağıtma kapasitesinin daha da geliştiğini belirtir. Dursun'a göre, modern kültür, görsele dayalı ve görülenin egemen olduğu bir kültürdür. Baktığımız her şeyi görmeyiz. Çünkü görmek, öncelikle duyu yönelimli olmakla birlikte, aslında bilişsel ve zihinsel bir iştir. Görme, nesnelerin dış imgeleri ile iç düşünce süreçleri arasındaki bağlantının bir ürünü olarak oluşur. Dış imgeler ve iç düşünce süreçleri içinde yaşanılan kültürel ortam tarafindan belirlenmektedir. Görsel kültür, toplumun kendi değerlerini, inanışlarını, deneyimlerini, göstergeler ve kodlarla görünür hale getirmesinin sonucunda ortaya çıkmaktadır. Resim, fotoğraf, film, televizyon, gazetecilik başlıca geleneksel görsel kültür biçimleridir. Dursun'a (2016) göre, görsel gerçekliğin en büyük sorunu, eleştirelliği ve düşünmeyi desteklememesi, gösteri dünyasın da görünen şeyin tam olarak gerçeği temsil etmemesidir. Bu anlamda "yeni medya teknolojileriyle güçlenen görsel kültür, gerçekliğin değersizleşmesine yol açarken, hakiki olan ile taklidi arasındaki ayrımın bulanıklaşmasına yol açmaktadır.

Bir sosyalleşme mekânı olarak sosyal medyaya yöneltilen diğer bir eleştiri konusu da bireylerin fikirlerini ve düşüncelerini özgürce ifade edebildikleri konusuna yöneliktir. "Sosyal medyada herkes fikirlerini özgürce ifade etmektedir" görüşünün aksine sosyal medya ortamlarında bireyler artık her görüşünü ifade etmediği, gözetlendiğinin farkında olduklarını söylemek mümkündür.

Sosyal medyada bireylerin kendileri gibi düşünen, kendisi gibi yaşam tarzına sahip insanlarla arkadışlık kurması beraberinde bireyi farklı görüş ve bakış açılara sahip insanlardan da uzaklaștırdığını söylenebilir. Bireyin sahip olduğu görüș, bakıș açısı kendisi gibi düşünen insanlar tarafından onaylanması, pekiştirilmesi, bireyi farklı görüş ve dünya görüşlerinden haberdar olmaktan uzaklaştırabilmektedir.

Sosyal medya kişileri bir taraftan bireyselleştirirken, diğer taraftan da sanal mekânda yeni ve farklı bir şekilde toplumsallaştırması söz konusudur. $\mathrm{Bu}$ toplumsallaşma biçimi hareketsiz, bedensiz, dolaylı ve yapay bir toplumsallaşmadır. Sosyal medya ağları bireyin aile, arkadaşlık, mahalle ve komşuluk ilişkilerini değiştirmekte ve dönüştürmektedir. Sosyal medya kullanımı, kişiler arası ilişkileri, ifade etme şekillerini, okul başarısını, aile içi iletişimi, sosyal çevre ile etkileşimi gibi gündelik hayatındaki pek çok konuyu etkisi altına aldığı ve şekillendirdiği ifade edilmektedir. İnsanlar artık uzak ya da yakın mesafedeki arkadaşlık ilişkilerini sosyal ağlar üzerinden yürütmekte, bu ortamlarda kendini ifade etmektedir. Sosyal medya ile yapılan arkadaşlıkların gerçek hayattaki arkadaşlıkların tam olarak yerini tutmadığını, sanal ortamların bireyi aile ortamındaki etkileşimden, mahalle ve sokak kültüründen, komşuluk ilişkilerinden uzaklaştırdığını söylemek mümkündür.

Karagülle ve Çaycı, bireylerin sosyal ağlar üzerinden iletişim kurmaya başlamasının geleneksel iletişim biçimlerini değiştirdiğini, bu değişmenin de toplumsal yabancılaşma ve yalnızlaşmayı beraberinde getirdiğini ifade etmektedirler. "Sosyal iletişimin yaygın hale gelmesiyle, modern insanlar yüz yüze iletişim kurmak için yeterli zaman bulamamaktadır. Yaşanan bu gelişmelerle birlikte; alışkanlıklar, düşünceler, duygular da değişerek; sanal yaşam, sanal davranış ve sanal kültür olarak adlandırılan kavramlar ortaya çıkmıştır. Bu çerçevede, sosyal yaşantıda meydana gelen değişimler, bireyleri yalnızlığa sürükleyerek; yabancılaşma ve yalnızlaşma sürecine götürmektedir." Günümüzde sosyal paylaşım ağları, hayatımızın vazgeçilmez bir parçası olarak yer almaktadır. Sosyalleşme mekânları zaman içerisinde dönüşüme uğrayarak; teknolojinin de gelişmesiyle birlikte, gerçek anlamda yüz yüze görüşmenin önüne geçerek bir araya gelme gereksinimine duyulan ihtiyacın azalmasına neden olmaktadır. Sosyal paylaşım ağları bireylere, zaman ve mekândan bağımsız olarak iletişim 
kurma imkanı tanıyarak; sanal ortamlarda bir araya gelme imkanı tanımaktadır (Karagülle ve Çayc1, 2014, s. 2).

Sosyal medyada geçirilen zamanın gerçek hayattaki insanlarla geçirilen zamandan daha fazla hale gelmesi bireyin sosyal bağlarını zayıflatması ve asosyalleşmesini beraberine getirebilmektedir. "Modern yaşam, her ne kadar bireysel ve toplumsal olan arasında daha fazla iletişime yol açsa da; ileri teknoloji, hızlı toplumsal ve kültürel değişimler, gerçek dünyanın sanal olana kayması gibi etkenler, bireylerin uyum mekanizmalarını bozmakta ve bireylerin topluma ve kendi doğalarına uyumsuz hale gelerek; sadece bireysel çıkarları doğrultusunda hareket etmeye başlamalarına neden olmaktadır" (Karagülle ve Çaycı, 2014, s. 4).

Sanal iletişim; beden dilinin (mimikler, jestler, göz teması), dokunma duyusunun olmadığı, duyguların üretilmiş hazır simgelerle ifade edildiği bir iletişim biçimidir. Sanal sosyalleşme fiziksel temasın ve gerçekliğe ait bir mekânın olmadığı bir yapay iletişim şeklidir. Sanal iletişim sanal bir yaşam ve kültürü, sanal davranışları ortaya çıkarır. Sosyal medyada yapılan paylaşımlar, sürdürülen arkadaşlıklar, sahip olunan özgürlükler, güvenlik, ünlü olma gibi pek çok kavramlar gerçeğin yerini alarak gerçekmiş algısı yaratabiliyor.

Duran Okur ve Özkul'a göre, "sosyal paylaşım siteleri günümüz bireyi ve özellikle yeni kuşak bireyler için ikinci bir sosyal ortam oluşturmaktadır. Gerçek sosyal ortamların adeta bir alternatifi olarak hayatımıza giren bu siteler, tıpkı gerçek yaşamdaki gibi her yönüyle ideal ilişkiler kurulmasını sağlamamaktadır. Bireyler kurdukları ilişkiler içerisinde, gerçek ortamlardaki gibi partnerlerinin denetimi altındadırlar ve hatta gerçek yaşamdaki gibi denetim mekanizmaları tarafindan denetlenmektedirler. Farklı olan tek bir tarafi vardır ki o da, bedensel temasın olmamasıdır" (Duran Okur ve Özkul, 2015, s. 240). Günümüz dünyasında hayat tecrübelerimiz artık dijital ortamların getirdiği görsel medya ile sürekli bir biçimde dolayımlanmaktadır. İnsanın dünyaya dair anlam üretimi bütün iletişim araçlarının sağladığı aracılık (dolayımlama) sayesinde olmaktadır. Yaşadığımız dönemde anlam üretimi yazıdan ve sözden daha çok görsel öğelerle yapılmaktadır. Görselliğin bu şekilde yoğun oluşu gerçeklik algımızı dönüştürmekte ve gerçekliğin ortadan kalkmasına sebep olmaktadır (Dursun, 2013, s. 167).

Sosyal medya ile ilgili diğer önemli bir konu da bu mekânlarda dolaşımda olan bilginin niteliği ve doğruluğu ile ilgilidir. Bozkurt'a göre, günümüzde bilginin yaygınlaşmasında en önemli etkenlerden bir tanesi olan internet, bir o kadar da bilginin kirlenmesinde rol oynamaktadır. "İnternet sayesinde isteyen herkes istediği bir bilgiyi hiçbir denetime tabi tutulmadan milyonlara aktarabilmektedir. Bu bilgiler faydalı bilgiler olabileceği gibi niteliksiz yasal olmayan bilgilerde olabilmektedir" (Bozkurt, 2006, s. 36-37). Sosyal medyada dolaşan bilgiler magazinel ve dedikoduya dayalı denetlenemeyen bir bilgi olarak yaygınlık gösterirken, doğruluğu kanıtlanmış bilginin sayısı ise azdır. Bu anlamda bireyler dolaşımdaki bilginin doğruluğundan emin değildirler.

İletişim teknolojileri tarihinde ilk kez internet aracılığıyla bireyler, iletişimde bulunduğu "ötekinin” biyolojik ve toplumsal varlığını, sesini, görüntüsünü, cinsiyetini, kısaca bireysel özelliklerini dikkate almaksızın iletişimde bulunabilmektedir. Hiç tanımadığı birine karşı kendi kimliğini gizleyerek, ismini, cinsiyetini, toplumsal rolünü ve statüsünü değiştirerek iletişimde bulunması mümkün olmuştur. Bu yeni iletişim ortamlarında "anonimlik" bütünüyle geçerlidir. İletişim ise bu kurgulanmış kimlikler aracılığıyla yapılır hale gelmiştir (Timisi, 2003, s. 172). Online görünmezlik, kimliği bölünmüş ve akışkan hale getirmiş, bu durum sanal kimlik kılıfı altında bireye çoklu kimlikleri benimseme imkânı sağlamıştır (Karaduman, 2010).

Sosyal medya ortamında bireyler kendileri ile ilgili doğru beyanda bulunmayabiliyorlar. Kişi kendi gerçek kimliğini, karakterini gizleyerek sanal bir kimlik ve karakter inşa ederek diğerleriyle iletişime ve etkileşime geçebiliyor. $\mathrm{Bu}$ da dolayısıyla kişinin yalan söyleme potansiyelini artırarak, samimi, dürüst olmasını engelleyebiliyor. Sosyal medya ortamlarında bireyler dikkat çekmek, beğenilmek, mutlu olduğunu göstermek amaciyla s1k s1k kendi fotoğraflarını, bulunduğu mekânlarda yediklerini, içtiklerini, gezdikleri, eğlendikleri yerlerin fotoğraflarını çekip paylaşmaları yoğun bir şekilde gözlemlenen bir davranış şekli olarak karşımıza çıkabilmektedir. 
Kişiler sosyal medya ortamında sürekli kendilerini başkalarıyla kıyaslama çabası içine girerek ne kadar mutlu olduklarını gösterme çabasına girebilmektedirler. Sosyal medya etrafta çok sayıda mutlu insan varmış izlenimi yaratabilmekte, herkes sahip oldukları zenginliği, ev araba, tatil vb. ifşa etme çabası içine girebilmektedir. Kimin neyi paylaştığı, kimin neyi beğendiği, kimin nerede olduğu merak kışkırtılabilmekte, sanal ortamda birey ötekilere kendini ötekilere kanıtlama, kabul ettirme, beğendirme çabasına girmesi yaygın olarak ön plana çıkabilmektedir.

Bekiroğlu ve Hülür'e göre, sosyal medyada kimlikler, diğerinin beğenisine sunulan, değer biçilen ve üzerinde diğerinin şekillendirildiği birer emtiaya dönüşmüştür. "Birey, sosyal ağlarda kendini sergileyerek diğerinin beğenisini kazanmakta, böylece varlığını onun beğenisi ile anlamlı kılmakta ve meşrulaştırmaktadır. İnsanlar, sosyal ağlarda diğerinin sorunlarından çok, paylaştığı fotoğraf, gezdiği yer, yediği yemek ve yaptığı imâlı göndermelerle ilgilidir" (Bekiroğlu ve Hülür, 2016, s. 151). Mercan (2010), sosyal ağlarda bireylerin takipçi sayılarını arttırmak, tanınır olmak amacıyla sahte bir kimliğe bürünerek yeni sosyalleșme mekânları olarak adlandırılan ağlarda yer aldıklarını ifade etmektedir. Mercan'a göre bu durum, bireylerin gerçek dünyadaki kimlikleriyle, sanal dünyada yarattıkları sahte kimlikler, önemli sorunları beraberinde getirmekte; gerçek kimliği ile kendi yarattığı sahte kimliği iç içe geçen birey, kendi öz benliğine yabancılaşabilmektedir.

Oğuz'a (2016) göre sosyal medya, bireylere kendilerini ifade etmeleri ve sahip oldukları narsistik karakter özelliklerini diğer kişilere yansıtma konusunda son derece elverişli bir ortam sunmaktadır. "Sosyal medya görece serbestliği ile ilgili davranışların kolaylıkla diğger kişiler ile paylaşılmasına olanak sağlamaktadır. Durum güncellemeleri, fotoğraf paylaşımları, mesajlaşma özelliklerinin sıklıkla kullanılması ve bunun narsisizm ile bağlantılı olması son derece önemlidir; bu durum aynı zamanda narsisizmin boyutları arasında yer alan teşhircilik boyutunun da bir göstergesi olarak karşımıza çıkmaktadır" (s. 65). Narsizmde kişi kendisinin çok önemli biri olarak özel ve eşi bulunmaz biri olduğunu, amaçlarına ulaşmak için başkalarının zayıf yanlarını kullanması gerektiğini, çoğu zaman başkalarını kıskanarak başkalarının kendisini kıskandığını düşünür (s. 54).

\section{Yöntem}

$\mathrm{Bu}$ araştırma, üniversite öğrencilerinin bir sosyalleşme alanı olarak sosyal medya hakkındaki görüşleri; sosyal medya ortamlarındaki kültürel değerler, bilginin niteliği, ilişki biçimleri, ifade şekli, kültürel özellikler ve davranış özellikleri çerçevesinde incelemeyi amaçlamaktadır. Araştırma, betimleyici nitelikte bir araştırma olup veriler üniversite öğrencilerinden anket tekniği ile toplanmıştır.

Araştırmanın temel problemi; üniversite öğrencilerinin bir sosyalleşme alanı olarak sosyal medya ağları hakkında görüşlerinin neler olduğuna ilişkindir. Araştırmanın alt soruları ise şu şekilde belirtilmiştir.

1. Üniversite öğrencileri hangi sosyal medya kanallarını ne kadar süre ile kullanmaktadır?

2. Üniversite öğrencilerinin sosyal medya kullanım süreleri cinsiyetleri, yaşları ve gelirlerine göre nasıl bir dağılım göstermektedir?

3. Üniversite öğrencilerinin sosyal medyayı kullanma amaçları hakkındaki görüşleri nelerdir?

4. Sosyal medya ortamlarındaki kültürel değerler ile ilgili üniversite öğrencilerinin görüşleri nelerdir?

5. Sosyal medya ortamlarında paylaşılan bilginin niteliği ile ilgili üniversite öğrencilerinin görüşleri nelerdir?

6. Sosyal medya ortamlarındaki ilişki biçimlerine ilişkin üniversite öğrencilerinin görüşleri nelerdir?

7. Sosyal medya ortamlarında kişilerin kendini ifade etme şekline ilişkin üniversite öğrencilerinin görüşleri nelerdir? 
8. Sosyal medya ortamlarında sunulan kültürün özelliklerine ilişkin üniversite öğrencilerinin görüşleri nelerdir?

9. Sosyal medya ortamlarındaki kişilerin davranış özellikleri hakkında üniversite öğrencilerinin görüşleri nelerdir?

\section{Araştırmanın evren ve örneklemi}

$\mathrm{Bu}$ araştırmanın evrenini, Mersin Üniversitesi merkez kampüsünde yer alan Teknik Bilimler Meslek Yüksek Okulu (4065 öğrenci), Eğitim Fakültesi (2040 öğrenci), Fen Edebiyat Fakültesi (3287 öğrenci), Beden Eğitimi ve Spor Yüksekokulu (306 öğrenci), Güzel Sanatlar Fakültesi (414 öğrenci) ve İletişim Fakültesinde (576 öğrenci) (4 fakülte, 1 Yüksekokul ve 1 Meslek Yüksek Okul) birinci öğretimde kayıtlı 10.688 lisans ve ön lisans öğrencisi oluşturmaktadır. Sağlik bilimleri ile ilgili fakülte ve yüksekokullar dışındaki fakülte, yüksekokul ve meslek yüksekokullarından program türü çeşitliliği de dikkate alınarak, Mersin Üniversitesi 2018-2022 dönemi Stratejik Planında sunulan birinci öğretimde kayıtlı öğrenci sayıları temel alınarak \%95 güven aralığı ve $\pm \% 5$ yanılgı payı (Erkuş, 2005, s. 91) ile bu evreni temsil etme özelliğine sahip 394 kişilik bir örneklem tespit edilmiştir. Her fakültenin öğrenci sayısı belli olduğu için, tabakaların evrendeki ağırlığı hesaplanarak hangi fakülteden kaç kişiyle görüşüleceği belirlenmiştir. Örneklemde yer alan öğrencilerin özellikleri aşağıdaki tablolarda belirtilmiştir.

Tablo 1.

Öğrencilerin Fakülte, Bölüm, Cinsiyet ve Yaş Gruplarına İlişkin Frekans ve Yüzde Dağılımları

\begin{tabular}{lcc}
\hline Fakülteler & $\mathrm{f}$ & $\%$ \\
\hline Teknik Bilimler Meslek Yüksek Okulu & 75 & 19,0 \\
\hline Gida Teknolojisi & 18 & 4,6 \\
Mobilya ve Dekorasyon & 14 & 3,6 \\
İnşaat Teknolojisi & 22 & 5,6 \\
Ulaştırma ve Trafik Hizmetleri & 21 & 5,3 \\
\hline Eğitim Fakültesi & 75 & 19,0 \\
\hline Sinıf Öğretmenliği & 15 & 3,8 \\
Matematik Öğretmenliği & 15 & 3,8 \\
Fen Bilgisi Öğretmenliği & 15 & 3,8 \\
Psikolojik Danışma ve Rehberlik & 15 & 3,8 \\
İngilizce Öğretmenliği & 15, & 3,8 \\
\hline Fen Edebiyat Fakültesi & 63 & 16,0 \\
\hline Sosyoloji & 20 & 5,1 \\
Psikoloji & 20 & 5,1 \\
Tarih & 16 & 4,1 \\
Biyoloji & 7 & 1,8 \\
\hline Beden Eğitimi ve Spor Yüksekokulu & 60 & 15,2 \\
\hline Beden Eğitimi Öğretmenliği & 30 & 7,6 \\
Beden Eğitimi ve Spor Öğretmenliği & 30 & 7,6 \\
\hline Güzel Sanatlar Fakültesi & 60 & 15,2 \\
\hline Resim & 15 & 3,8 \\
Seramik & 15 & 3,8 \\
Tekstil & 15 & 3,8 \\
Heykel & 15 & 3,8 \\
\hline İletişim Fakültesi & 61 & 15,5 \\
\hline Gazetecilik & 31 & 7,9 \\
Radyo ve Televizyon & 30 & 7,6 \\
\hline Cinsiyet & $\mathrm{f}$ & 59,5 \\
\hline Kadın & 195 & 50,5 \\
Erkek & & \\
\hline
\end{tabular}




\begin{tabular}{lcc}
\hline Yaş Gruplar1 & $\mathrm{f}$ & $\%$ \\
\hline $16-19$ yaş & 132 & 33,5 \\
20 yaş & 100 & 25,4 \\
21 yaş & 57 & 14,5 \\
$22+$ & 105 & 26,6 \\
\hline Gelir Gruplar1 & $\mathrm{f}$ & $\%$ \\
\hline 1600 Türk Liras1 ve alt1 & 122 & 31,0 \\
1700-2700 Türk Liras1 aras1 & 127 & 32,2 \\
2800-4000 Türk Lirasi aras1 & 73 & 18,5 \\
4000 Türk Liras1 ve üzeri & 72 & 18,3 \\
\hline Toplam & 394 & 100 \\
\hline
\end{tabular}

Araştırmaya katılan üniversite öğrencilerinin $\% 49,5$ 'i kadın, \%50,5'i erkektir. Ankete katılan üniversite öğrencilerinin \%33,5'i 16-19 yaş, \% 25,4'ü 20 yaş, \% 14'ü 21 yaş, \% 26,6's1 22 yaş ve üzerindedir. Araştırmaya katılan üniversite öğrencilerinin en düşün yaş 16, en yüksek yaş ise 43 olmuştur.

\section{Veri toplama}

Araştırmanın verileri araştırmacı tarafından geliştiren "Üniversite Öğrencilerinin Sosyalleşme Alanı Olarak Sosyal Medya Hakkındaki Görüşleri” adlı anket aracılığı ile toplanmıştır. Anket, araştırma soruları temelinde ve ilgili literatür taranarak ve uzman görüşü alınarak hazırlanmıştır. Anket formunda yer alan soruların anlaşılırlığı ve açıklığını belirleyebilmek için 50 öğrencinin katılımı ile bir pilot uygulama yapılmış ve anket yeniden düzenlenmiştir. Bu düzenlemede üniversite öğrencilerinin hangi sosyal medya araçlarını kullandıklarını belirlemek için sorulan soruda seçenekler çoğaltılmış ve diğer bölümlerde tekrar ettiği farkedilen maddeler çıkartılmıştır. Anket formu sekiz bölümden oluşmaktadır. İlk bölümde yer alan sorularla öğrencilerin cinsiyet, bölüm, sınıf, yaş, aile gelir durumu, sosyal medya kullanma durumları ile ilgili bilgileri elde etmek amaçlanmıştır. İzleyen bölümler ise üniversite öğrencilerinin sırasıyla sosyal medya kullanım amaçları, sosyal medya ortamlarındaki kültürel değerler, sosyal medya ortamlarında paylaşılan bilginin niteliği, sosyal medya ortamlarındaki ilişki biçimleri, sosyal medya ortamlarında kişilerin kendini ifade etme şekli, sosyal medya ortamlarında sunulan kültürün özellikleri ve sosyal medya ortamlarındaki kişilerin davranış özellikleri hakkındaki görüşlerini öğrenmek üzere "kesinlikle katılıyorum", "katılıyorum", "kararsızım", "katılmıyorum" ve "kesinlikle katılmıyorum" yanıt seçeneklerinden oluşan toplam 48 sorudan oluşmaktadır.

\section{Verilerin analizi}

Veriler önce kodlanmış ve SPSS paket programına yüklenmiştir. Araştırma alt problemleri izlenerek yürütülen frekans ve yüzdelik betimleyici istatistiksel teknikleri ile araştırmaya katılan üniversite öğrencilerinin bir sosyalleşme alanı olarak sosyal medya ağları hakkında görüşleri incelenmiştir.

\section{Bulgular}

\section{1. Üniversite öğrencileri hangi sosyal medya kanallarını ne kadar süre ile kullanmaktadır?}

Üniversite öğrencilerinin \%32'si 2 saat ve altında, \%40'1 2 saat 30 dakika ile 4 saat 30 dakika arasında, \%16's 5 saat ile 6 saat 30 dakika arasında, \%11'i ise 7 saat ve üzerinde sosyal medya ortamlarında zaman geçirdikleri görülmektedir. 
Tablo 2.

Öğrencelerin Sosyal Medya Kullanım Sürelerine İlişkin

Frekans ve Yüzdelik Dağılımlar

\begin{tabular}{lcc}
\hline Kullanım süreleri & $\mathrm{f}$ & $\%$ \\
\hline 2.00 saat alt1 & 127 & 32,2 \\
$2.30-4.30$ aras1 & 159 & 40,4 \\
$5.00-6.30$ aras1 & 65 & 16,5 \\
7 saat + & 43 & 10,9 \\
\hline Toplam & 394 & 100 \\
\hline
\end{tabular}

Tablo 3.

Öğrencelerin Sosyal Medya Kullanım Sürelerine İlişkin Minimum,

Maksimum ve Ortalama Değerleri

\begin{tabular}{lcccc}
\hline & Kişi sayıs1 & $\begin{array}{c}\text { Günlük } \\
\text { minimun }\end{array}$ & $\begin{array}{l}\text { Günlük } \\
\text { maksimum }\end{array}$ & Ortalama \\
\hline $\begin{array}{l}\text { Kullanım } \\
\text { süresi }\end{array}$ & 394 & $30 \mathrm{dk}$ & 15 saat & 4,16 saat \\
\hline
\end{tabular}

Üniversite öğrencilerinin sosyal medyayı en az kullanım süresi 30 dakika olurken, en fazla kullanım süresi ise 15 saat olmuştur. Üniversite öğrencilerinin günlük ortalama sosyal medya kullanım süresi ise 4 saat 15 dakika olmuştur.

Tablo 4.

Öğrencelerin Kullandıkları Sosyal Medya Kanalına İlişkin Frekans ve Yüzdelik Dağılımları

\begin{tabular}{|c|c|c|c|c|c|c|}
\hline Sosyal medya & & 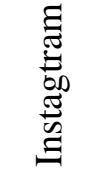 & 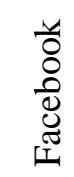 & 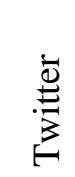 & 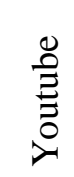 & 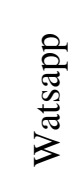 \\
\hline \multirow[t]{2}{*}{ Kullanıyorum } & $f$ & 362 & 91 & 185 & 341 & 361 \\
\hline & $\%$ & 92 & 23 & 47 & 87 & 91 \\
\hline \multirow[t]{2}{*}{ Kullanmiyorum } & $\mathrm{f}$ & 32 & 303 & 209 & 53 & 33 \\
\hline & $\%$ & 8 & 77 & 53 & 14 & 8 \\
\hline \multirow[t]{2}{*}{ Toplam } & $\mathrm{f}$ & 394 & 394 & 394 & 394 & 394 \\
\hline & $\%$ & 100 & 100 & 100 & 100 & 100 \\
\hline
\end{tabular}

Üniversite öğrencilerinin \%92'si Instagram, \%91'i Watsapp, \%87'si Youtube, \%47'si Twitter, \%23'ü ise Facebook kullandıkları görülmektedir. Öğrencilerin büyük bir kesiminin Instagram ve Watsapp'ı kullanırken en az Facebook'u kullandıkları dikkat çekmektedir.

2. Üniversite ögrrencilerinin sosyal medya kullanım süreleri cinsiyetleri, yaşları ve gelirlerine göre nasıl bir dă̆ılım göstermektedir?

Tablo 5'i incelediğimizde 7 saat ve üzeri sosyal medya kullanan üniversite öğrencisi kadınların oranı $\% 16$, erkeklerin oran $1 \% 6$ olmuştur. 5 saat ile 6,30 saat arası kullanan kadınların oranı $\% 29$, erkeklerin oranı ise \%18 olmuştur. 2,30 saat ile 4,30 saat arası sosyal medya kullanan üniversite öğrencisi kadınların oranı $\% 41$, erkelerin ise $\% 40$ oranında birbirine yakın iken; 2 saat ve altında sosyal medya kullanan kadınların oranı $\% 28$, erkelerin oranı ise $\% 36$ oranında olmuştur.

$\mathrm{Bu}$ dağılımlardan hareketle, üniversite öğrencisi kadınların erkeklere oranla sosyal medyada geçirdikleri sürenin daha fazla olduğunu söylemek mümkündür. 
Tablo 5.

Öğrencilerin Cinsiyete Göre Sosyal Medya Kullanım Süreleri

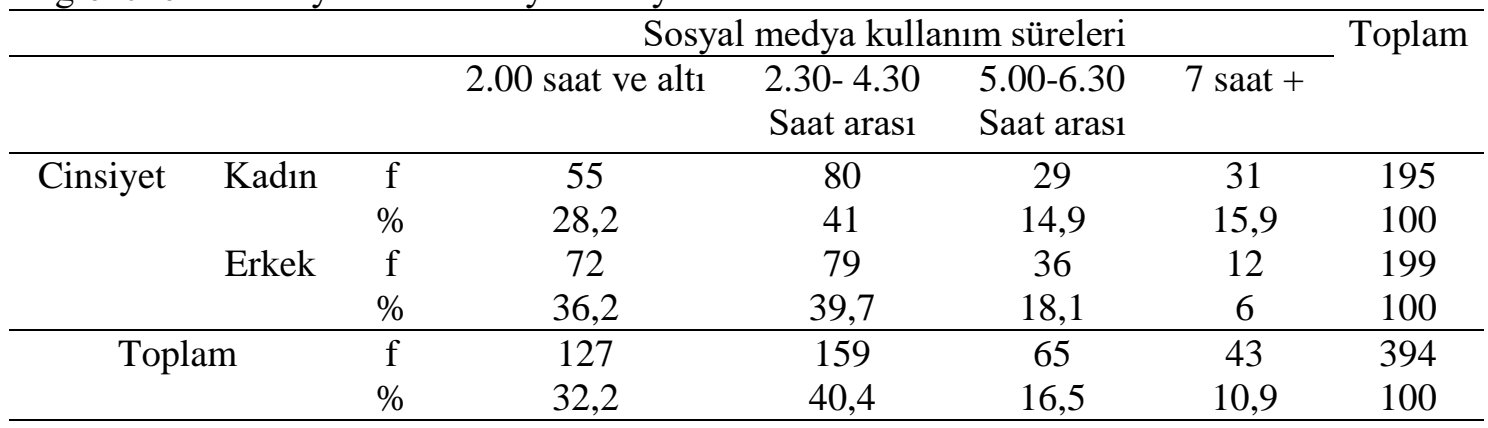

Tablo 6.

Öğrencilerin Yaş Gruplarına Göre Sosyal Medya Kullanım Süreleri

\begin{tabular}{|c|c|c|c|c|c|c|c|}
\hline & & & \multicolumn{4}{|c|}{ Sosyal medya kullanma süresi } & \multirow[t]{2}{*}{ Toplam } \\
\hline & & & $\begin{array}{c}2.00 \text { saat } \\
\text { altı }\end{array}$ & $\begin{array}{c}2.30- \\
4.30\end{array}$ & $\begin{array}{c}5.00- \\
6.30\end{array}$ & $\begin{array}{c}7 \text { saat } \\
+\end{array}$ & \\
\hline \multirow{8}{*}{$\begin{array}{c}\text { Yaş } \\
\text { grupları }\end{array}$} & $16-19$ & $\mathrm{f}$ & 33 & 54 & 23 & 22 & 132 \\
\hline & yaş & $\%$ & 25,0 & 40,9 & 17,4 & 16,7 & 100 \\
\hline & 20 yaş & $\mathrm{f}$ & 27 & 48 & 14 & 11 & 100 \\
\hline & & $\%$ & 27,0 & 48,0 & 14,0 & 11,0 & 100 \\
\hline & 21 yaş & $\mathrm{f}$ & 22 & 17 & 14 & 4 & 57 \\
\hline & & $\%$ & 38,6 & 29,8 & 24,6 & 7,0 & 100 \\
\hline & $22+$ & $\mathrm{f}$ & 45 & 40 & 14 & 6 & 105 \\
\hline & & $\%$ & 42,9 & 38,1 & 13,3 & 5,7 & 100 \\
\hline \multirow{2}{*}{\multicolumn{2}{|c|}{ Toplam }} & & 127 & 159 & 65 & 43 & 394 \\
\hline & & & 32,2 & 40,4 & 16,5 & 10,9 & 100 \\
\hline
\end{tabular}

Tablonun bütününü incelediğimizde üniversite öğrencilerinin \%32'si 2 saat ve altında, $\% 40$ '1 2,30 ile 4,30 saat arasında, \%17'si 5 ile 6,30 saat, \%11'i 7 saat ve üzeri sosyal medyada zaman geçirdikleri görülmektedir. Yaş gruplarına göre tabloyu incelediğimizde 16-19 yaş grubundaki üniversite öğrencilerinin en çok $\% 40,9,20$ yaş grubundaki üniversite öğrencilerinin de en çok \%48, 22 yaş üzeri öğrencilerin de en çok \%40 ile 2,30-4,30 saat arası sosyal medyada zaman geçirdikleri anlaşılmaktadır. 2 saat ve altında sosyal medyada zaman geçiren 16-19 yaş grubundaki üniversite öğrencilerinin oran $\% 25,20$ yaş grubundaki öğrencilerin oranı $\% 27,21$ yaş grubundakilerin oran $1 \% 38,22$ yaş ve üstü ögrencilerin oranı ise $\% 45$ olarak görülmektedir. 7 saat ve üzeri sosyal medya kullanan öğrencilerin yaş gruplarına göre dağılımı ise sırasıyla 1619 yaş aras $\% 17,20$ yaş $\% 11,21$ yaş \%7, 22 yaş ve üzeri ise $\% 6$ oranında olmuştur. Bu dağılımlardan hareketle üniversite öğrencilerinin yaş oranları düştükçe sosyal medya da geçirdikleri süre arttığı, öğrencilerin yaşları yükseldikçe sosyal medyada geçirdikleri sürenin düştüğü tespit edilmiştir.

Tablo 7'yi incelediğimizde tüm gelir gruplarında öğrencilerin sosyal medyada geçirdikleri süre en fazla $\% 40$ oranında 2,30-4,30 saat arası olduğu görülmektedir. Tüm gelir gruplarında öğrencilerin \%10'unun sosyal medyada 7 saat ve üzerinde, \%16'sinın 5 ile 6,30 saat arası zaman geçirmesi dikkat çekicidir.

Ailesi 1600 lira ve altı gelire sahip olan öğrenciler \%43 oranında en fazla 2,30-4,30 saat arası sosyal medyada zaman geçirdiklerini belirtmişlerdir. 1700 ile 2700 lira arası gelir grubundaki öğrencilerin de en çok \%37 ile 2,30- 4,30 saat arası sosyal medyada zaman geçirdikleri, 2800 ile 4000 lira arası gelir grubundaki öğrenciler \%39,7 ile 2,30- 4,30 saat aras1 sosyal medyada zaman geçirdikleri, 4000 ve üzeri gelir grubundaki öğrencilerin $\% 41,7$ ile 2,304,30 saat arası sosyal medyada zaman geçirdiklerini belirtmişlerdir. 
Tablo 7.

Öğrencilerin Gelir Gruplarına Göre Sosyal Medya Kullanım Süreleri

\begin{tabular}{|c|c|c|c|c|c|c|c|}
\hline & & & \multicolumn{4}{|c|}{ Sosyal medya kullanma süresi } & \multirow[t]{2}{*}{ Toplam } \\
\hline & & & $\begin{array}{c}2.00 \text { saat } \\
\text { alt1 }\end{array}$ & $\begin{array}{c}2.30- \\
4.30\end{array}$ & $\begin{array}{c}5.00- \\
6.30\end{array}$ & $\begin{array}{c}7 \text { saat } \\
+\end{array}$ & \\
\hline & 1600 lira ve & $\mathrm{f}$ & 37 & 53 & 16 & 16 & 122 \\
\hline \multirow{9}{*}{ grupları } & alt1 & $\%$ & 30,3 & 43,4 & 13,1 & 13,1 & 100 \\
\hline & 1700-2700 lira & $\mathrm{f}$ & 43 & 47 & 26 & 11 & 127 \\
\hline & aras1 & $\%$ & 33,9 & 37,0 & 20,5 & 8,7 & 100 \\
\hline & 2800-4000 lira & $\mathrm{f}$ & 22 & 29 & 15 & 7 & 73 \\
\hline & aras1 & $\%$ & 30,1 & 39,7 & 20,5 & 9,6 & 100 \\
\hline & 4000 ve üzeri & $\mathrm{f}$ & 25 & 30 & 8 & 9 & 72 \\
\hline & & $\%$ & 34,7 & 41,7 & 11,1 & 12,5 & 100 \\
\hline & olam & $f$ & 127 & 159 & 65 & 43 & 394 \\
\hline & & $\%$ & 32,2 & 40,4 & 16,5 & 10,9 & 100 \\
\hline
\end{tabular}

7 saat ve üzeri sosyal medyada en fazla zaman geçiren grup \%13,1 ile 1600 lira ve altı gelir grubundan öğrenciler olmuştur. 2 saat ve altında sosyal medyada zaman geçiren 1600 lira ve altı gelir grubundaki üniversite öğrencilerinin oran $\% 30,3$ tür. 7 saat ve üzeri sosyal medyada en az zaman geçiren grup ise \%9,6 ile 2800-4000 lira arası gelir grubu olmuştur.

$\mathrm{Bu}$ dağılımlardan hareketle üniversite öğrencilerinin gelirleri düştükçe sosyal medya da geçirdikleri süre arttığı, öğrencilerin gelirleri yükseldikçe sosyal medya da geçirdikleri sürenin düştüğü tespit edilmiştir.

\section{3. Üniversite ögrencilerinin sosyal medyayı kullanma amaçları hakkındaki görüşleri nelerdir?}

Tablo 8.

Öğrencilerin Sosyal Medyayı Kullanma Amaçları Hakkındaki Görüşleri

\begin{tabular}{|c|c|c|c|c|c|c|c|}
\hline Sosyal medya araçlarını; & & 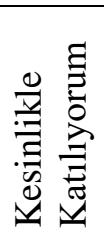 & 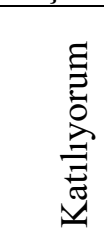 & 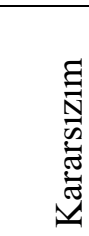 & 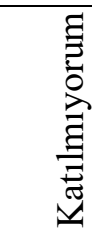 & 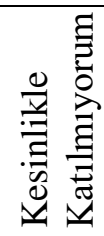 & $\begin{array}{l}\frac{\Xi}{0} \\
\text { 。 } \\
0\end{array}$ \\
\hline \multirow{2}{*}{$\begin{array}{l}\text { 1. Arkadaşlarımla iletişim kurmak için } \\
\text { kullanıyorum. }\end{array}$} & $\mathrm{f}$ & 189 & 164 & 24 & 13 & 4 & 394 \\
\hline & $\%$ & 48 & 41,6 & 6,1 & 3,3 & 1,0 & 100 \\
\hline \multirow{2}{*}{$\begin{array}{l}\text { 2. Oyun oynamak, eğlenmek, zaman geçirmek için } \\
\text { kullanıyorum. }\end{array}$} & f & 123 & 157 & 38 & 50 & 26 & 394 \\
\hline & $\%$ & 31,2 & 39,8 & 9,6 & 12,7 & 6,6 & 100 \\
\hline \multirow[t]{2}{*}{ 3. Kültürel açıdan bilgilenmek için kullanıyorum. } & f & 135 & 182 & 55 & 13 & 9 & 394 \\
\hline & $\%$ & 34,3 & 46,2 & 14,0 & 3,3 & 2,3 & 100 \\
\hline \multirow[t]{2}{*}{ 4. Sohbet etmek için kullanıyorum. } & $\mathrm{f}$ & 147 & 184 & 31 & 26 & 6 & 394 \\
\hline & $\%$ & 37,3 & 46,7 & 7,9 & 6,6 & 1,5 & 100 \\
\hline \multirow[t]{2}{*}{ 5. Eğitim amaçlı kullanıyorum. } & $\mathrm{f}$ & 102 & 185 & 56 & 39 & 12 & 394 \\
\hline & $\%$ & 25,9 & 47,0 & 14,2 & 9,9 & 3,0 & 100 \\
\hline \multirow[t]{2}{*}{ 6. Yeni arkadaşlar bulmak amacıyla kullanıyorum. } & f & 27 & 52 & 74 & 136 & 105 & 394 \\
\hline & $\%$ & 6,9 & 13,2 & 18,8 & 34,5 & 26,6 & 100 \\
\hline \multirow{2}{*}{$\begin{array}{l}\text { 7. Arkadaşlarımın ne yaptığını kontrol etmek için } \\
\text { kullanıyorum. }\end{array}$} & $\mathrm{f}$ & 51 & 101 & 77 & 96 & 69 & 394 \\
\hline & $\%$ & 12,9 & 25,6 & 19,5 & 24,4 & 17,5 & 100 \\
\hline \multirow{2}{*}{$\begin{array}{l}\text { 8. Video, müzik, resim, fotoğraf paylaşımı için } \\
\text { kullanıyorum. }\end{array}$} & f & 127 & 176 & 42 & 36 & 13 & 394 \\
\hline & $\%$ & 32,2 & 44,7 & 10,7 & 9,1 & 3,3 & 100 \\
\hline \multirow[t]{2}{*}{ 9. Kendimi ifade etmek için kullanıyorum. } & f & 56 & 126 & 97 & 84 & 31 & 394 \\
\hline & $\%$ & 14,2 & 32,0 & 24,6 & 21,3 & 7,9 & 100 \\
\hline \multirow{2}{*}{$\begin{array}{l}\text { 10. Kişi ve sosyal grupları takip etmek amacıyla } \\
\text { kullanıyorum. }\end{array}$} & $\mathrm{f}$ & 116 & 178 & 40 & 40 & 20 & 394 \\
\hline & $\%$ & 29,4 & 45,2 & 10,2 & 10,2 & 5,1 & 100 \\
\hline
\end{tabular}


Sosyal medyayı kullanma amaçları hakkındaki görüşler kesinlikle katılıyorum ve katılıyorum ile kesinlikle katılmıyorum ve katılmıyorum cevapları birlikte değerlendirildiğinde; öğrencilerin \%89'u arkadaşlarıyla iletişim kurmak, \%84'ü sohbet etmek için kullandıkları görülmektedir. Öğrencilerin \%71'i oyun oynamak, eğlenmek ve zaman geçirmek, \%80’i kültürel açıdan bilgilenmek, \%70'i eğitim amaçl1, \%80'i video, müzik, resim, fotoğraf paylaşımı, \% 74'ü kişi ve sosyal grupları takip etmek amacıyla kullandıklarını ifade etmişlerdir. Öğrencilerin \%39'u arkadaşlarımın ne yaptığını kontrol etmek amacıyla, \%46'sı kendilerini ifade etmek amacıyla kullandıklarını belirtmişlerdir.

4. Sosyal medya ortamlarındaki kültürel değerler ile ilgili üniversite ögrrencilerinin görüsleri nelerdir?

Tablo 9.

Öğrencilerin Sosyal Medya Ortamlarındaki Kültürel Değerler Hakkındaki Görüşleri

\begin{tabular}{|c|c|c|c|c|c|c|c|}
\hline Sosyal medya ortamında insanların; & & 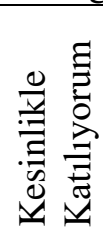 & 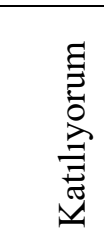 & 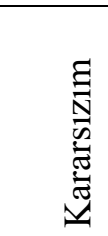 & 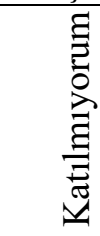 & 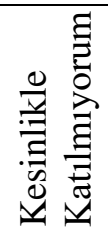 & 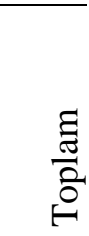 \\
\hline \multirow{2}{*}{$\begin{array}{l}\text { 1. Dürüst ve samimi davrandıklarını } \\
\text { düşünüyorum. }\end{array}$} & $\mathrm{f}$ & 10 & 30 & 91 & 124 & 139 & 394 \\
\hline & $\%$ & 2,5 & 7,6 & 23,1 & 31,5 & 35,3 & 100 \\
\hline \multirow{2}{*}{$\begin{array}{l}\text { 2. Yardımsever olduklarını } \\
\text { düşünüyorum. }\end{array}$} & f & 4 & 43 & 159 & 111 & 77 & 394 \\
\hline & $\%$ & 1,0 & 10,9 & 40,4 & 28,2 & 19,5 & 100 \\
\hline \multirow{2}{*}{$\begin{array}{l}\text { 3. Gerçek dostluk ilişkileri yaşadığını } \\
\text { düşünüyorum. }\end{array}$} & $\mathrm{f}$ & 7 & 28 & 111 & 137 & 111 & 394 \\
\hline & $\%$ & 1,8 & 7,1 & 28,2 & 34,8 & 28,2 & 100 \\
\hline \multirow[t]{2}{*}{ 4. Bencil olduklarını düşünüyorum. } & f & 66 & 103 & 153 & 55 & 17 & 394 \\
\hline & $\%$ & 16,8 & 26,1 & 38,8 & 14,0 & 4,3 & 100 \\
\hline \multirow[t]{2}{*}{ 5. Kıskanç olduklarını düşünüyorum } & $\mathrm{f}$ & 71 & 103 & 142 & 57 & 21 & 394 \\
\hline & $\%$ & 18,0 & 26,1 & 36,0 & 14,5 & 5,3 & 100 \\
\hline \multirow{2}{*}{$\begin{array}{l}\text { 6. Ulusal değerleri güçlendirdiğini } \\
\text { düşünüyorum. }\end{array}$} & f & 19 & 61 & 132 & 105 & 77 & 394 \\
\hline & $\%$ & 4,8 & 15,5 & 33,5 & 26,6 & 19,5 & 100 \\
\hline 7. Dini değerleri güçlendirdiğini & $\mathrm{f}$ & 9 & 30 & 119 & 107 & 129 & 394 \\
\hline düşünüyorum. & $\%$ & 2,3 & 7,6 & 30,2 & 27,2 & 32,7 & 100 \\
\hline
\end{tabular}

Sosyal medya ortamlarındaki kültürel değerlere ilişkin görüşler kesinlikle katılıyorum ve kat1liyorum ile kesinlikle katılmiyorum ve katılmıorum cevapları birlikte değerlendirildiğinde; öğrencilerin $\% 61$ 'i sosyal medya ortamındaki insanların samimi davranmadıklarını, \%48'i yardımsever olmadıklarını, \%63'ü gerçek dostluk ilişkileri yaşamadıklarını belirtmişlerdir. Öğrencilerin \% 46'sı sosyal medya ortamlarının ulusal değerleri güçlendirmediğini belirtmekte ancak \%33'ü bu konuda kararsız olduklarını bildirmektedir. Öğrencilerin \%60'^ sosyal medyanın değerleri güçlendirmediğini \%30'u ise bu konuda kararsız olduklarını belirtmişlerdir.

5. Sosyal medya ortamlarında paylaşılan bilginin niteliği ile ilgili üniversite ögrencilerin görüşleri nelerdir?

Sosyal medya ortamlarında paylaşılan bilginin niteliğine ilişkin görüşler, kesinlikle kat1lyorum ve kat1liyorum ile kesinlikle katılmıyorum ve katılmıorum cevapları birlikte değerlendirildiğinde; öğrencilerin \%54'ünün paylaşılan bilgilerin çoğunlukla bilimsel nitelikli bulmadı̆̆ı, \%28'inin bu konuda kararsız oldukları görülmektedir. Öğrencilerin \%37'si sosyal medyanın entelektüel kültürü, \%40’ı genel kültürü artırdığını ifade etmişs, \%11'i bilgilerin 
doğruluğundan emin olduğunu buna karşın \%54'ü bilgilerin çoğunlukla magazin ve dedikodu içerdiğini ifade etmişlerdir.

Tablo 10.

Öğrencilerin Sosyal Medya Ortamlarında Paylaşılan Bilginin Niteliği İle İlgili Görüşleri

Sosyal medya ortamlarında paylaşılan bilgilerin;

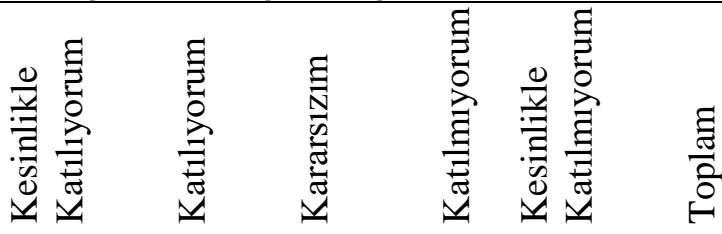

\begin{tabular}{lcrrrrrr}
\hline 1.Çoğunlukla bilimsel nitelikli & $\mathrm{f}$ & 14 & 55 & 111 & 153 & 61 & 394 \\
bilgiler olduğunu düşünüyorum. & $\%$ & 3,6 & 14,0 & 28,2 & 38,8 & 15,5 & 100 \\
\hline 2. Entelektüel kültürümü artırdığını & $\mathrm{f}$ & 31 & 115 & 136 & 76 & 36 & 394 \\
düşünüyorum. & $\%$ & 7,9 & 29,2 & 34,5 & 19,3 & 9,1 & 100 \\
\hline 3. Doğruluğundan eminim. & $\mathrm{f}$ & 5 & 39 & 138 & 118 & 94 & 394 \\
& $\%$ & 1,3 & 9,9 & 35,0 & 29,9 & 23,9 & 100 \\
\hline 4. Çoğunlukla magazin ve dedikodu & $\mathrm{f}$ & 120 & 164 & 54 & 43 & 13 & 394 \\
bilgileri içerdiğini düşünüyorum. & $\%$ & 30,5 & 41,6 & 13,7 & 10,9 & 13,3 & 100 \\
\hline 5. Genel kültürümü artırdığını & $\mathrm{f}$ & 35 & 122 & 140 & 63 & 34 & 394 \\
düşünüyorum. & $\%$ & 8,9 & 31,0 & 35,5 & 16,0 & 8,6 & 100 \\
\hline
\end{tabular}

6. Sosyal medya ortamlarındaki iliş̧ki biçimlerine iliş̧kin üniversite öğrencilerinin görüşleri nelerdir?

Tablo 11.

Öğrencilerin Sosyal Medya Ortamlarındaki İlişki Biçimleri Hakkındaki Görüşleri

Sosyal medya araçlarını;

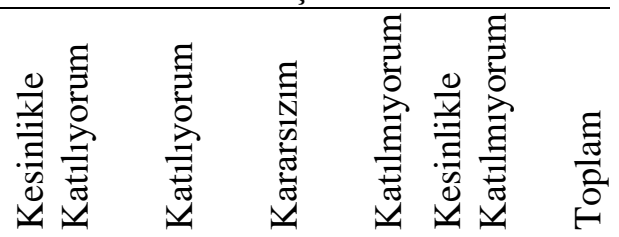

\begin{tabular}{llllllll}
\hline 1.Sosyal medya kullanmanın aile ilişkilerimi & $\mathrm{f}$ & 12 & 33 & 69 & 152 & 128 & 394
\end{tabular}

\begin{tabular}{lrrrrrrr} 
güçlendirdiğini düşünüyorum. & $\%$ & 3,0 & 8,4 & 17,5 & 38,6 & 32,5 & 100 \\
\hline 2. Sosyal medyadaki ilișkilerin bir aile ilișkisinin & $\mathrm{f}$ & 12 & 24 & 41 & 112 & 205 & 394
\end{tabular}

\begin{tabular}{lrrrrrrr} 
yerini tuttuğunu düşünüyorum. & $\%$ & 3,0 & 6,1 & 10,4 & 28,4 & 52,0 & 100 \\
\hline
\end{tabular}

\begin{tabular}{llrrrrrr}
\hline 3. Sosyal medyadaki arkadaşlığın gerçek bir & f & 159 & 113 & 48 & 38 & 36 & 394
\end{tabular}

\begin{tabular}{lrrrrrrr} 
arkadaşlığın yerini tutmadı̆̆ını düşünüyorum. & $\%$ & 40,4 & 28,7 & 12,2 & 9,6 & 9,1 & 100 \\
\hline 4. Sosyal medyada çok arkadaşımın olmasını tercih & $\mathrm{f}$ & 12 & 36 & 71 & 158 & 117 & 394
\end{tabular}

\begin{tabular}{lrrrrrrr} 
ediyorum. & $\%$ & 3,0 & 9,1 & 18,0 & 40,1 & 27,7 & 100 \\
\hline 5. Sosya
\end{tabular}

\begin{tabular}{llrrrrrr}
\hline 5. Sosyal medyadaki diyaloglar, paylaşımlar, & f & 33 & 65 & 97 & 107 & 92 & 394
\end{tabular} $\begin{array}{llllllll}\text { etkinliklerin gerçek sosyal hayattan daha eğlenceli } & \% & 8,4 & 16,5 & 24,6 & 27,2 & 23,4 & 100\end{array}$ ve keyif verici olduğunu düşünüyorum.

\begin{tabular}{llllllll}
\hline 6. Sosyal medyadaki arkadaşlık ilişkilerinin & f & 107 & 142 & 74 & 48 & 23 & 394
\end{tabular} \begin{tabular}{lrrrrrrr} 
çoğunlukla yapay olduğunu düşünüyorum & $\%$ & 27,2 & 36,0 & 18,8 & 12,2 & 5,8 & 100 \\
\hline 7. Sosyal medyadaki arkadaşlarımla sohbet etmek, & $\mathrm{f}$ & 46 & 79 & 78 & 105 & 86 & 394
\end{tabular} \begin{tabular}{lrrrrrrr} 
7. Sosyal medyadaki arkadaşlarımla sohbet etmek, & f & 46 & 79 & 78 & 105 & 86 & 394 \\
yüz yüze konuşmak kadar beni tatmin ediyor. & $\%$ & 11,7 & 20,1 & 19,8 & 26,6 & 21,8 & 100 \\
\hline
\end{tabular} \begin{tabular}{llrrrrrr}
\hline 8. Sosyal medyada genellikle benimle benzer & f & 48 & 170 & 85 & 67 & 24 & 394
\end{tabular}

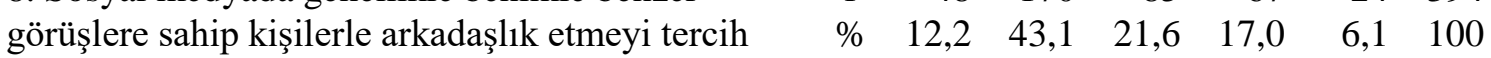
ediyorum.

\begin{tabular}{llllllll}
\hline 9. Sosyal medyada arkadaşlarımın paylaşımlarını & f & 46 & 139 & 89 & 70 & 50 & 394
\end{tabular}

$\begin{array}{llllllll}\text { beğenerek onları mutlu ettiğimi düşünüyorum } & \% & 11,7 & 35,3 & 22,6 & 17,8 & 12,7 & 100\end{array}$


Sosyal medya ortamlarındaki ilișki biçimleri hakkındaki görüșler kesinlikle katılıyorum ve katılıyorum ile kesinlikle katılmiyorum ve katılmiyorum cevapları birlikte değerlendirildiğinde; öğrencilerin \%11'inin sosyal medyanın aile ilişkilerini güçlendirdiğini, \%9'unun sosyal medyadaki ilişkilerin bir aile ilişkisinin yerini tuttuğunu, \%18'inin sosyal medyadaki arkadaşlığın gerçek bir arkadaşlı̆̆ın yerini tuttuğunu, \%38'inin sosyal medyadaki iletişimin gerçek hayattaki gibi eğlenceli ve keyif verdiğini ifade ettikleri görülmektedir. Üniversite öğrencilerinin \%63’ü sosyal medya ortamındaki arkadaşlık ilişiklerinin yapay olduğunu, \%55'i sosyal medyada kendisine benzer görüşteki kişilerle arkadaşlık etmeyi tercih ettiğini, \%47'si arkadaşlarının paylaşımlarını beğenerek onları mutlu ettiğini düşünmektedirler.

\section{Sosyal medya ortamlarında kişilerin kendini ifade etme şekline ilişkin üniversite ögrencilerinin görüslleri nelerdir?}

Tablo 12.

Öğrencilerin Sosyal Medya Ortamlarında Kişilerin Kendini İfade Etme Şekli Hakkındaki

Görüssleri

Sosyal medya ortamlarında;
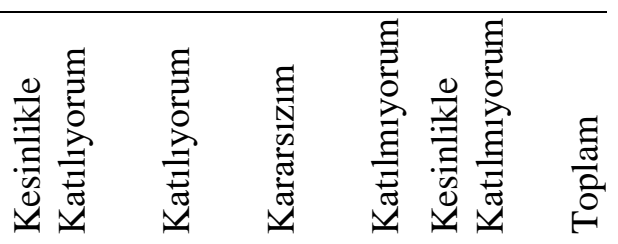

1. İstediğim düşünceleri, duyguları, fikirleri

\begin{tabular}{crrrrrr}
$\mathrm{f}$ & 67 & 125 & 77 & 69 & 56 & 394 \\
$\%$ & 17,0 & 31,7 & 19,5 & 17,5 & 14,3 & 100 \\
\hline $\mathrm{f}$ & 43 & 108 & 98 & 91 & 54 & 394 \\
$\%$ & 10,9 & 27,4 & 24,9 & 23,1 & 13,7 & 100 \\
\hline $\mathrm{f}$ & 60 & 201 & 79 & 37 & 17 & 394 \\
$\%$ & 15,2 & 51,0 & 20,1 & 9,4 & 4,3 & 100 \\
\hline $\mathrm{f}$ & 52 & 124 & 71 & 100 & 47 & 394 \\
$\%$ & 13,2 & 31,5 & 18,0 & 25,4 & 11,9 & 100 \\
$\mathrm{f}$ & 15 & 44 & 100 & 121 & 114 & 394 \\
$\%$ & 3,8 & 11,2 & 25,4 & 30,7 & 28,9 & 100 \\
\hline
\end{tabular}

özgürce ifade edebiliyorum.

2. Herkesin istediği gibi duygu ve düşüncelerini

ifade edebildiğini düșünüyorum.

3. Bana ait mesajların, fikirlerin, fotoğrafların

beğenildiğini görünce hoşuma gidiyor.

4. İnsanlarla yüz yüze konuşamadığım konuları, çok daha rahat bir şekilde konuşabiliyorum.

5. Kendimi sosyal hayattakinden daha güvende hissediyorum.

Sosyal medya ortamlarında kișilerin kendini ifade etme şekli hakkındaki görüşleri kesinlikle katılıyorum ve katılıyorum ile kesinlikle katılmıyorum ve katılmıyorum cevapları birlikte değerlendirildiğinde; öğrencilerin \%48'i istediği duygu düşünce ve fikirleri ifade edebildiğini, \%38'i herkesin istediği gibi duygu ve düşüncelerini ifade edebildiğini, \%15'i kendini sosyal medyada sosyal hayattakinden daha güvende hissettiklerini ifade ettikleri görülmektedir. Öğrencilerin \%66's1 sosyal medyada kendisine ait fikirlerin ve fotoğrafların beğenildiğinde hoşuna gittiğini, \% 44'ü insanlarla konuşamadığı konuları sosyal medyada daha rahat ifade edebildiğini belirtmişlerdir.

8. Sosyal medya ortamlarındaki kültürün özelliklerine ilişkin üniversite ögrrencilerinin görüşleri nelerdir?

Sosyal medya ortamlarında yer alan kültürün özellikleri hakkındaki görüşler kesinlikle katılıyorum ve katılıyorum ile kesinlikle katılmıyorum ve katılmıyorum cevapları birlikte değerlendirildiğinde; öğrencilerin \%83'ü sosyal medya ortamında kişilerin kendilerini başkalarıyla kıyaslama çabası içinde oldukları, \%82'si kişilerin kendilerini mutlu oldukları gösterme çabası içinde oldukları düşüncesine sahip oldukları tespit edilmiştir. Üniversite öğrencilerinin \%86'sı insanların sosyal medyada kendilerini kanıtlama ve beğendirme çabası içinde olduklarını, \%80'i insanların sahip oldukları şeyleri gösterme ve ifşa etme çabası içinde olduklarını, \%77'si insanların birbirini dikizlediklerini ifade etmektedirler. Sosyal medyada yapılan paylaşımlarda şiddet içerikleriyle karşılaştıklarını belirten öğrencilerin oranı \%51 iken 
bu konuda kararsızların oranı ise \%29 olmuştur. Öğrencilerin \%84'ü sosyal medyada istemediği reklamlara maruz kaldığını belirtmektedirler.

Tablo 13.

Öğrencilerin Sosyal Medya Ortamlarında Yer Alan Kültürün Özellikleri Hakkındaki Görüşleri

Sosyal medya ortamlarında;

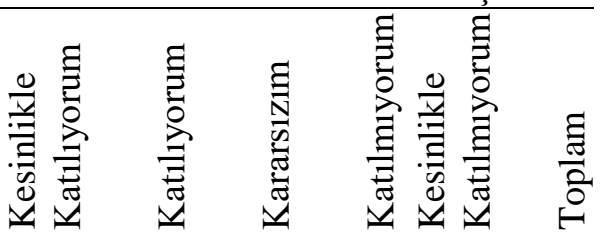

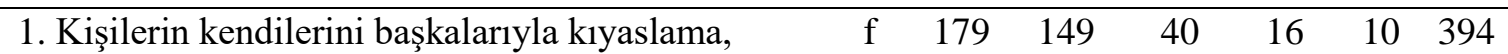

$\begin{array}{llllllll}\text { (güzellik, sahiplik ve zenginlik anlamında) } & \% & 45,4 & 37,8 & 10,2 & 4,1 & 2,5 & 100\end{array}$

karşılaştırma çabası içinde olduğunu düşünüyorum.

\begin{tabular}{lrrrrrrr}
\hline 2. Genellikle insanların hep mutlu olduklarını & $\mathrm{f}$ & 190 & 136 & 46 & 17 & 5 & 394 \\
gösterme çabası içinde olduğunu düşünüyorum & $\%$ & 48,2 & 34,5 & 11,7 & 4,3 & 1,3 & 100 \\
\hline 3. İnsanların genelde kendilerini kanıtlama ve & $\mathrm{f}$ & 199 & 142 & 36 & 12 & 5 & 394 \\
beğendirme çabası içinde olduklarını düşünüyorum. & $\%$ & 50,5 & 36,0 & 9,1 & 3,0 & 1,3 & 100 \\
\hline 4. İnsanların sahip oldukları şeyleri gösterme, ifşa & $\mathrm{f}$ & 187 & 128 & 64 & 10 & 5 & 394 \\
etme çabası içinde olduklarını düşünüyorum. & $\%$ & 47,5 & 32,5 & 16,2 & 2,5 & 1,3 & 100 \\
\hline 5. İnsanların birbirlerini dikizlediklerini & $\mathrm{f}$ & 153 & 148 & 68 & 18 & 7 & 394 \\
düşünüyorum. & $\%$ & 38,8 & 37,6 & 17,3 & 4,6 & 1,8 & 100 \\
\hline 6. Yapılan paylaşımlarda şiddet içerikleriyle & $\mathrm{f}$ & 77 & 123 & 114 & 62 & 18 & 394 \\
karşlaş1yorum. & $\%$ & 19,5 & 31,2 & 28,9 & 15,7 & 4,6 & 100 \\
\hline 7. İstemediğim reklamlara maruz kalıyorum. & $\mathrm{f}$ & 211 & 124 & 30 & 21 & 8 & 394 \\
& $\%$ & 53,6 & 31,5 & 7,6 & 5,3 & 2,0 & 100 \\
\hline
\end{tabular}

9. Sosyal medya ortamlarındaki kişilerin davranış özellikleri hakkında üniversite ögrrencilerinin görüşleri nelerdir?

Sosyal medya ortamlarındaki kişilerin davranış özellikleri hakkındaki görüşler kesinlikle kat1lyorum ve kat1lıyorum ile kesinlikle katılmıyorum ve katılmıyorum cevapları birlikte değerlendirildiğinde; öğrencilerin \%75'inin sosyal medyada bireylerin kendileri ile ilgili doğru açıklamalarda bulunmadıklarını, \%79'unun kişilerin kendilerini gizlediklerini, \%74'ünün kişilerin sanal kimlik ve karakter kullandıklarını düşündükleri anlaşılmaktadır. Öğrencilerin \%74'ü mutsuz ve yalnız insanların sosyal medyada daha çok zaman geçirdiklerini ifade etmişlerdir.

Tablo 14.

Öğrencilerin Sosyal Medya Ortamlarındaki Kişilerin Davranış Özellikleri Hakkındaki Görüşleri

Sosyal medya ortamlarinda; $\quad$ 辛

\begin{tabular}{lrrrrrrr}
\hline 1. Bireylerin kendileri ile ilgili çoğunlukla doğru & $\mathrm{f}$ & 137 & 159 & 64 & 24 & 10 & 394 \\
açıklamalarda bulunmadıklarını düşünüyorum. & $\%$ & 34,8 & 40,4 & 16,2 & 6,1 & 2,5 & 100 \\
\hline 2. Kişilerin kendi kişiliklerini gizlediklerini & $\mathrm{f}$ & 122 & 190 & 59 & 18 & 5 & 394 \\
düşünüyorum. & $\%$ & 31,0 & 48,2 & 15,0 & 4,6 & 1,3 & 100 \\
\hline 3. Kişilerin sanal kimlik ve karakter kullandıklarını 1 & $\mathrm{f}$ & 125 & 167 & 79 & 19 & 4 & 394 \\
düşünüyorum. & $\%$ & 31,7 & 42,4 & 20,1 & 4,8 & 1,0 & 100 \\
\hline 4. Mutsuz ve yalnız insanların daha çok zaman & $\mathrm{f}$ & 170 & 122 & 70 & 25 & 7 & 394 \\
geçirdiğini düşünüyorum. & $\%$ & 43,1 & 31,0 & 17,8 & 6,3 & 1,8 & 100 \\
\hline
\end{tabular}




\section{Değerlendirme ve Sonuç}

Toplumu sosyo-kültürel anlamda kuşatma altına alan dijital iletişim teknolojileri, gündelik hayatın her alanına sızarak bireylerin ilişiklerine, yaşam tarzları ve alışkanlıklarına etki ederek değiştirmekte ve dönüştürmektedir. Bireylerin iletişim kurma ve sosyalleşme biçimleri, sosyalleşme mekânları, yaşam tarzları, ilişkileri farklı bir hal alarak hızlı bir evrim sürecinden geçmektedir. Sosyal medya platformları genelde günümüz toplumunu anlamak, özelde üniversite gençliğinin geçirdiği değişimi ve farklılaşmayı anlamlandırmak açısından önem arz etmektedir.

Üniversite öğrencilerinin bir sosyalleşme alanı olarak sosyal medya hakkındaki görüşlerini ele alan bu çalışmanın bulguları doğrultusunda şu sonuçlara ulaşılmıştır:

1. Üniversite öğrencilerinin sosyal medya kullanma süreleri ile ilgili görüşleri değerlendirildiğinde; üniversite öğrencilerinin sırasılyla \%92'sinin Instagram, \%91'inin Watsapp, \%87'sinin Youtube, \%47'sinin Twitter, \%23'ünün ise Facebook kullandıkları görülmektedir. Öğrencilerin büyük bir kesiminin Instagram ve Watsapp kullanırken en az Facebook'u kullandıkları dikkat çekmektedir. Üniversite öğrencilerinin sosyal medyayı bir gün içinde en az kullandıkları süre 30 dakika olurken, en fazla kullanım süresi 15 saat olmuştur. Üniversite öğrencilerinin günlük ortalama sosyal medya kullanım süresi ise 4 saat 15 dakika olmuştur. Buradan hareketle üniversite öğrencilerinin günlük olarak sosyal medya ortamlarında geçirdiği sürenin yüksek olduğunu söylemek mümkündür. Sosyal medya paylaşım ağları üniversite öğrencileri tarafından yoğun bir şekilde kullanılması sosyal medyanın sosyal ilişkiler açısından ne kadar önemli hale geldiği gündelik iletişim ve sosyalleşmenin bu alanlarda yoğunlaştığını bize göstermektedir. Öğrenciler iletişim kurma, haberleşme, oyun oynama, eğlenme, boş zaman değerlendirme amaçlı günlük zamanların büyük bir bölümünü bu ortamlarda yaşayarak geçirmektedirler. Sosyal medya araçları üniversite öğrencilerinin sosyalleşme şekillerinde bir değişim ve dönüşüm oluşturmakla birlikte gençler bu değişimin kısmen farkında olup, bu alanda geçirilen zaman gerçek hayattaki insanlarla geçirilen zamandan daha fazla hale gelmesi bireyin sosyal bağlarını zayıflatması ve asosyalleşme riskini beraberinde getirmektedir.

2. Üniversite öğrencilerinin cinsiyete göre sosyal medya kullanım süreleri değerlendirildiğinde; üniversite öğrencisi kadınların erkeklere oranla sosyal medyada geçirdikleri sürenin daha fazla olduğunu söylemek mümkündür. Üniversite öğrencilerinin yaş gruplarına göre sosyal medya kullanım süreleri değerlendirildiğinde; üniversite öğrencilerinin yaş oranları düştükçe sosyal medya da geçirdikleri süre artmakta olduğu, öğrencilerin yaşları yükseldikçe sosyal medya da geçirdikleri sürenin düştüğü tespit edilmiştir. Üniversite öğrencilerinin gelir gruplarına göre sosyal medya kullanım süreleri değerlendirildiğinde; üniversite öğrencilerinin gelirleri düştükçe sosyal medya da geçirdikleri sürenin arttı̆g öğrencilerin gelirleri yükseldikçe sosyal medya da geçirdikleri sürenin düştüğü tespit edilmiştir.

3. Üniversite öğrencilerinin sosyal medyayı kullanma amaçları hakkındaki görüşleri değerlendirildiğinde; üniversite öğrencileri arkadaşlarıyla iletişim kurmak ve sohbet etmek, oyun oynamak, eğlenmek, zaman geçirmek, kültürel faaliyetlerde bulunmak, kişi ve sosyal grupları takip etmek, video, müzik, resim, fotoğraf paylaşımlarında bulunmak amacı ile sosyal medya kullandıklarını ifade etmişlerdir. Araştırmada üniversite öğrencilerinin yaygın görüşün aksine sosyal medyayı daha çok arkadaş bulmak amacı ile kullanmadıkları, kendilerini ifade etme platformu olarak kullanmadıkları belirlenmiştir. İçinde yaşadığımız dönemde insanlar sosyal medya aracılığı ile kendi gündelik hayatları ile ilgili, sevdikleri ile ilgili bilgileri, fotoğrafları, videoları paylaşmaktadır. Resim, fotoğraf, film, başlıca görsel kültür biçimleridir. Görsel gerçekliğin en büyük sorunu, eleştirelliği ve düşünmeyi desteklememesi, gösteri dünyasında görünen şeyin tam olarak gerçeği temsil etmemesidir.

Sosyal medyanın bireylerin sosyalleşmesi, birbirlerine olan davranış şekillerini, yaşam ve iletişim kurma biçimlerini değiştirmesi açısından önemi büyüktür. Sosyal medyanın hayatımıza dahil olması ile birçok şey değişmiştir (Kök, 2013, s. 46). İnsanlarla girdiği toplumsal paylaşım ağları ile birlikte bireylerin iletişim biçimi değişmiş, karşılıklı paylaşım ve etkileşim unsurları yeni bir boyut kazanmıştır. Günümüzde sosyal medya araçları diğer 
sosyalleşme araçlarından daha farklı bir etkiye ve öneme sahip olarak karşımıza çıkmaktadır. Sosyal medya ortamları içinde yaşayan birey bilgi, duygu, düşünce, inanç, tutum ve davranışları etkileme ve etkilenmeye daha açık bir haldedir. Bireyler toplumda olup bitene ilişkin haber ve bilgileri, dünyaya ilişkin haberleri, bilgileri çoğunlukla ilk olarak sosyal medya kanalları üzerinden öğrenmektedir. Sosyalleşme, eğlenme, günlük olaylar hakkında haberdar olma, iletişim kurma, arkadaş bulma, oyun oynama, zaman geçirme vb. faaliyetlerin çoğu sosyal medya üzerinden gerçekleşir hale gelmiştir.

4. Sosyal medya ortamlarındaki kültürel değerler ile ilgili üniversite öğrencileri sosyal medya ortamlarında diğer insanların dürüst ve samimi davranmadıklarını, yardımsever olmadıklarını, gerçek dostluk ilişkileri yaşamadıklarını, bencil ve kıskanç olduklarını, sosyal medyanın ulusal ve dini değerleri güçlendirmediklerini düşünmektedirler. $\mathrm{Bu}$ anlamda üniversite öğrencilerinin sosyal medya ortamlarında cereyan eden kültürel unsurlarla ilgili daha çok olumsuz fikirler beyan ettikleri anlaşılmaktadır. Bireyin sosyalleştiği bu ortamlarda bireylerin dürüst olmadığını düşünmesi, samimi davranışların sergilenmediğini belirtmesi, gerçek anlamda dostluk ve arkadaşlık ilişkisi yaşanmadığını söylemesi, kendi ulusal ve dini değerlerine olumlu anlamda bir katkı sağlamadığını belirtmesi düşündürücüdür.

5. Sosyal medya ortamlarında paylaşılan bilginin niteliği ile ilgili üniversite öğrencileri sosyal medya ortamlarındaki bilginin çoğunlukla bilimsel nitelikli bilgiler olmadığını, entelektüel kültürlerini arttırdığı konusunda kararsız olduğu, bilgilerin doğruluğundan emin olmadıklarını, genel kültürü artırdığı konusunda kararsız olduklarını ve çoğunlukla magazin ve dedikoduya dayalı bilgileri içerdiğini ifade etmektedirler. Bu sonuç sosyal medyada dolaşan bilgilerin magazinsel ve dedikoduya dayalı denetlenemeyen, dezenformasyon ve manipülasyona açık bir bilgi olarak yaygınlık gösterdiği, doğruluğu kanıtlanmış bilginin sayısının az olduğu fikrini desteklemektedir.

6. Sosyal medya ortamlarındaki ilişki biçimlerine ilişkin üniversite öğrencileri sosyal medya kullanımlarının aile ilişkilerini güçlendirmediğini, sosyal medyadaki ilişkilerin bir aile ilişkisinin yerini tutmadığını, sosyal medyadaki arkadaşlığın gerçek bir arkadaşlığın yerini tutmadığını düşünmektedirler. Üniversite öğrencileri sosyal medyada çok arkadaşlarının olmasını tercih etmediklerini, sosyal medyadaki ilişkilerin gerçek hayattaki kadar keyif vermediğini düşündüklerini ifade etmektedirler. Ayrıca üniversite öğrencileri çoğunlukla sosyal medyada genellikle kendilerine benzer görüşlere sahip kişilerle arkadaşlık etmeyi tercih ettiklerini, sosyal medyada arkadaşlarının paylaşımlarını beğenerek onları mutlu ettiğini düşünmektedirler.

$\mathrm{Bu}$ anlamda iletişim ortamlarının dönüşümüyle, sosyalleşme dediğimiz olgu da farklılaşmıştır (Bakıroğlu, 2013). Günümüzde sanal alemde her şey, her olay, her olgu, ilişki şekli, bilgi edinme, bilgi paylaşma şeklinin geleneksel dönemden oldukça farklılaştığını söylemek mümkündür. Sosyal medyadaki ilişki biçimine ilişkin öğrencilerin dolaylı, aracılanmış iletişim yerine yüz yüze iletişimin daha tercih edilebilir ve sağlıklı olduğu açısından bir farkındalığa sahip olduklarını göstermektedir.

Sosyal medya ağları sosyal hayatın vazgeçilmez bir parçası haline gelerek sosyalleşme biçimini dönüşüme uğratmakta; yüz yüze görüşmenin önüne geçerek bireylere, zaman ve mekandan bağımsız bir iletişim şeklini ortaya çıkarmaktadır (Karagülle ve Çaycı, 2014, s. 2). $\mathrm{Bu}$ anlamda sosyal medyanın, bireyleri, zamanla gerçek ilişkilerinden uzaklaştırarak sanal arkadaşlıklar ve sanal iletişimin içine çekmesi, uzun vadede bu durumun kişilerde yalnızlaşmayı arttırabileceği riski taşıdığını söylemek mümkündür. Aynı zamanda sosyal medya ortamlarında öğrencilerin kendileri gibi düşünen insanlarla sürekli temas kurması farklı kişiler ve gruplardan uzaklaşması, sahip olunan görüşün, bakış açısının sürekli pekişmesi, ötekinin görüş ve bakış açılarına yabancılaşmasını getirebilecektir. $\mathrm{Bu}$ anlamda toplumsal uyum, uzlaşı, birlik, beraberlik, bütünlüğün sağlanması düşüncesine olumsuz bir yansıma olacağı gerçektir.

7. Sosyal medya ortamlarında kişilerin kendini ifade etme şekline ilişkin üniversite öğrencilerinin görüşleri değerlendirildiğinde elde edilen bulgular, öğrenciler kendileri dahil olmak üzere, herkesin istediği düşünceleri, duyguları, fikirleri özgürce ifade edemediği, bu ortamlarda kendilerini güvende hissetmediklerini ortaya koymaktadır. Sosyal medyaya yönelik 
bireyin kendini güvende hissettiği, herkes kendisini daha rahat ve özgürce ifade ettiği gibi yaygın yaklaşımların değiştiği görülmektedir. Sosyal medya etrafta çok sayıda mutlu insan varmış izlenimi yaratabilmekte, herkes sahip olduklarını, zenginliği, ev araba, tatil vb. ifşa etme çabası içine girebilmektedir. Kimin neyi paylaştığı, kimin neyi beğendiği, kimin nerede olduğu merakları kışkırtılabilmekte, sanal ortamda bireyler ötekilere kendini kanıtlamak, kabul ettirmek, beğendirme çabasına girme yaygın olarak ön plana çıkabilmektedir.

Beğenmek ve beğenilmek üzerine kurulmuş sosyal medya platformları, insanların bir başkasının onayına bağlı olarak yaşam tarzlarını yönlendirebileceğini empoze edebilmektedir (Aktaş, 2017, s. 1). Sosyal ağlar, popüler olmak, güncel olmak ve dolayısıyla beğenilmek için kullanıcıların daha fazla online olma ihtiyacını desteklemektedir (Bekiroğlu ve Hülür, 2016, s. 158). Sosyal medya ortamlarında birey kendi hayatını teşhir ederken hem öteki insanları ne yaptıklarına ilişkin gözetlemekte hem de kendisi özel hayatını bütün çıplaklığıyla mahremiyetini gözler önüne sermektedir.

Birey sosyal medyanın sunduğu imkânlardan faydalanırken özgür olduğu hissine kapılabilmekte, bu özgürlük yanılsaması ile gözetlediğini ve gözetlendiğini düşünmeden, umursamadan dilediğini yapabilmektedir. Sosyal medya bir yandan gözetim kültürünü yaygınlaştırırken, diğer taraftan gözetimi bir eğlence aracı olarak sunmakta ve bu gözetim oyununa, hazza bireyleri gönüllü olarak katılmasını sağlamaktadır.

8. Üniversite öğrencilerinin sosyal medya ortamlarındaki kültürün özellikleri hakkındaki görüşleri değerlendirildiğinde çok büyük bir çoğunluğun sosyal medya ortamlarında diğer insanların kendileri ile ilgili çoğunlukla doğru açıklamalarda bulunmadıklarını, samimi olmadıklarını, kişiliklerini gizlediklerini, sanal kimlik ve karakter kullandıklarını ifade ettikleri görülmektedir. Üniversite öğrencilerinin sosyal medya kullanıcılarının kimlikleri konusundaki ifadeleri; sosyal medya kullanıcıları birden fazla kimlik kullandıkları, sosyal medyada görünen kişilerin kimliklerinden tam olarak emin olunamadığ 1 ve onlarla sağlıklı iletişim kurabilmenin zorluğu, insanların istediği kimliğe bürünebildiği gibi düşünceleri desteklediği görülmektedir.

9. Üniversite öğrencilerinin sosyal medya ortamlarındaki kişilerin davranış özellikleri hakkındaki görüşlerine baktığımızda bireylerin kendileri ile ilgili doğru açıklamalarda bulunmadıklarını, kişilerin kendilerini gizledikleri, kişilerin sanal kimlik ve karakter kullandıklarını düşündükleri anlaşılmaktadır. Öğrenciler mutsuz ve yalnız insanların sosyal medyada daha çok zaman geçirdiklerini ifade etmektedirler. Sosyal ağlarda neyin gerçek neyin sahte olduğunu ayırt etmek zorlaşmaktadır.

Sanal arkadaşlıkların gerçek arkadaşlıkların yerini tam olarak tutmaması ve bireyin kendisini daha da yalnız hissetmesi, gerçek hayatta asosyalleşmesi ve buna bağlı olarak yaşam tarzının değişmesi gibi faktörler ön plana çıkabilmektedir. Özellikle başkalarının ne düşündüğünü, hissettiğini öğrendiğimiz sosyal medya, davranışlarımızı etkileyebilen ve/veya şekillendirebilen çok güçlü bir araç olduğunu belirtmektedirler. Baym ve Boyd'a (2012) göre sosyal medya varlık ve yokluk, zaman ve mekan, kontrol ve özgürlük, bireysel ve kitlesel iletişim, özel ve kamusal, sanal ve gerçek arasındaki sınırları bulanıklaştırmaktadır. Karagülle ve Çaycı, bireylerin sosyal ağlar üzerinden iletişim kurmaya başlamasının geleneksel iletişim biçimlerini değiştirdiğini, bu değişmenin de toplumsal yabancılaşma ve yalnızlaşmayı beraberinde getirdiğini ifade etmektedirler (Karagülle ve Çayc1, 2014, s. 1)

Özellikle bireyin başkaları tarafından beğenilme ve takdir edilme isteği, gerçek hayatta olmak isteyip de olamadığ 1 durumları gerçekleştirebilecekleri bir mekân firsatı vermesi gerçek kimliklerin ortaya koyulmasına engel oluşturabilmektedir. Sosyal medya ortamında bireylerin kendileri ile ilgili doğru beyanda bulunmaması, gerçek kimliğini, karakterini gizleyerek sanal bir kimlik ve karakter inşa etmesi kişinin yalan söyleme potansiyelini artırarak, normal hayatta da samimi, dürüst olmasını engelleyebileceği, öz benliğine yabancılaşacağı gerçeğini göz önünde bulundurmak gerekir. 


\section{Kaynaklar}

Aktaş, A. S. (2017). Yetişkin bireylerde sosyal medya kullanım davranışları ile yalnızlık düzeyi arasındaki ilişkinin değerlendirilmesi (Yayımlanmamış yüksek lisans tezi). Üsküdar Üniversitesi, İstanbul.

Armağan, A. (2013). Gençlerin sanal alanı kullanım tercihleri ve kendilerini sunum taktikleri: bir araştırma. Uluslararası Sosyal Araştırmalar Dergisi, 6(27), 78-92

Bakıroğlu, C. (2013). Sosyalleşme ve kimlik inşası ekseninde sosyal paylaşım ağları. Akademik Bilişim Konferansl, Antalya, Türkiye.

Baş, G. (2015). Eleştirel sosyal medya okuryazarlı̆̆ bağlamında yeni medyada imaj, görüntü ve beden sunumu (Yayımlanmamış yüksek lisans tezi). Ege Üniversitesi, İzmir.

Baym, N. ve Boyd, D. (2012). Socially mediated publicness: An introduction. Journal of Broadcasting and Electronic Media, 56(3).

Bayrak, H. (2018, 6 Şubat). 2018 İnternet Kullanımı ve Sosyal Medya İstatistikleri. 15 Mayıs 2018 tarihinde Erişim adresi: https://dijilopedi.com/2018-internet-kullanimi-ve-sosyalmedya-istatistikleri/

Bekiroğlu, H. A. ve Hülür, A. B. (2016). Üniversite öğrencilerinin facebook kullanımı ve dijital şizofreni üzerine bir araştırma. OÜSBAD, (146-175).

Bozkurt, V. (2006). Endüstriyel ve post endüstriyel dönüşüm-bilgi, ekonomi, kültür. Bursa: Ekin Kitabevi.

Duran Okur, H. ve Özkul, M. (2015). Modern iletişimin ara yüzü: Sanal iletişim sosyal paylaşım sitelerinin toplumsal ilişki kurma biçimlerine etkisi (facebook örneği). Süleyman Demirel Üniversitesi Sosyal Bilimler Enstitüsü Dergisi, 1(21), 213-246.

Durmuş B. ve diğerleri. (2010). Facebook'tayız sosyal paylaşım ağlarının bireylere ve işletmelere yönelik incelenmesi: facebook üzerine bir araştırma. İstanbul: Beta Basım Yayım Dağıtım.

Dursun, Ç. (2016). Sözlü yazılı ve görsel kültürde insan ve toplum. Erişim adresi: http://eogrenme.anadolu.edu.tr/eKitap/SOS315U.pdf

Erkuş, A. (2005). Bilimsel araştırma sarmalı. Ankara: Seçkin Yayınları.

Göker, G. ve Demir, M. ve Doğan, A. (2010). Ağ toplumunda sosyalleşme ve paylaşım: Facebook üzerine ampirik bir araştırma. E-Journal of New World Sciences Academy dergisi, 5(2), 183-206.

Güçdemir, Y. (2010). Sanal ortamda iletişim-bir halkla ilişkiler perspektifi. İstanbul: Derin Yayınlar1.

Gürsakal, N. (2009). Sosyal ăg analizi. Bursa: Dora Yayıncılık.

Hazar, M. (2011). Sosyal medya bağımlılı̆̆ı: Bir alan çalışması. Iletişsim, Kuram ve Araştırma Dergisi, 32, 151-175.

Hürriyet (2010, 18 Ekim). Facebook bir özgüven sorunu. 20 Haziran 2018 Erişim adresi: http://www.hurriyet.com.tr/gundem/facebook-bir-ozguven-sorunu-16010299

Karaduman, S. (2010). Modernizmden postmodernizme kimliğin yapısal dönüşümü. Journal of Yaşar University, 17(5), 2886-2899.

Karagülle, A. E. ve Çaycı, B. (2014). Ağ toplumunda sosyalleşme ve yabancılaşma. The Turkish Online Journal of Design, Art and Communication, 4(1), 1-9

Kenyon, G. ve McPherson, B. (1974). Approach to the study of sport socialization. International Review of Sport Sociology, 9(1), 127.129.

Kök, A. (2013). Günümüz toplumsal ortamında kişilerarası ilişkilerdeki dönüşümün sosyal medyayı kullanan çocuklar üzerinden incelenmesi (Yayımlanmamış yüksek lisans tezi). Ege Üniversitesi, İzmir.

Korkmaz, İ. (2013). Facebook ve mahremiyet: Görmek ve gözetle(n)mek. Yalova Sosyal Bilimler Dergisi, 5, 107-122.

Kuşay, Y. (2003). Sosyal medya ortamı olarak facebook'un çekiciliği ve ergenlerde bağımlılık düzeyi (Yayınlanmamış doktora tezi). Marmara Üniversitesi, İstanbul.

Mercan, N. (Ocak 2010). Dijital dünyada zaman, mekan, insan ilişkileri ve yabancılaşma. Silahll Kuvvetler Dergisi, 403, 100-111. 
Oğuz, T. (2016). Çağdaş narkisisos'lar: facebook kullanım alışkanlıkları ve narsisizm. Selçuk Iletişim, 9(2), 51- 68.

Özdemir, Z. (2015). Sosyal medyada kimlik inşasında yeni akım: özçekim kullanımı. Maltepe Üniversitesi İletişim Fakültesi Dergisi, 2(1), 112-131.

Sabah, (2018, 19 Mart ). Dünyada 3 milyar 190 bin kişi sosyal medya kullanıyor. 15 Haziran 2018 tarihinde Erişim adresi: https://www.sabah.com.tr/teknoloji/2018/03/19/dunyada3-milyar-190-bin-kisi-sosyal-medya-kullaniyor

Timetürk (2012, 18 Eylül ). Facebook gençliği kimlik krizi yaşıyor. 15 Haziran 2018 tarihinde Erişim adresi: https://www.timeturk.com/tr/2012/09/18/facebook-gencligi-kimlik-kriziyasiyor.html

Timisi, N. (2003). Yeni iletişim teknolojileri ve demokrasi. Ankara: Dost Yayınları.

Timisi, N. (2005). Sanalı gerçekliği internetin kimlik ve topluluk alanlarına giriş. M. Binark ve B. Kılıçbay (Yay. haz.). Internet, Toplum, Kültür içinde (ss. 89-105). Ankara, Epos Yayınları.

Toprak, A. ve diğerleri (2009). Toplumsal paylaşım ă̆l facebook: "Görülüyorum öyleyse varım!'. İstanbul: Kalkedon Yayınları.

Tutgun Ünal, A. (2015). Sosyal medya bağımlılı̆ğ: üniversite öğrencileri üzerine bir araştırma (Yayımlanmamış doktora tezi). Marmara Üniversitesi, İstanbul.

Uluç G. ve Yarcı A. (2017). Sosyal medya kültürü. Dumlupınar Üniversitesi Sosyal Bilimler Dergisi, 52, 88-102.

Uzundumlu, Ö. (2015). Bir iletişim formu olarak sosyal medyada fotoğraf paylaşımı: selfie örneği (Yayımlanmamış yüksek lisans tezi). Atatürk Üniversitesi, Erzurum.

\section{Extended Abstract}

\section{Introduction}

Social media, which is the most important and increasingly becoming widespread among the mass media, is now one of the most important issues of social life. The importance of digital platforms where people share information, documents, news is increasing all over the world day by day. While social media provide facilities to individuals such as being able to express themselves, to have close relations with people who have common aspects, to have quick information about what is happening in the world; it brings a change to relationships in family, neighborhoods, friendships. With the spread of communication technologies, the forms of socialization have changed and the forms of socialization and spaces of real life have been replaced by virtual environments. University students are one of the leading social media users. The youth period, which is one of the main points of the socialization process, constitutes an important stage to be examined in this context. In this sense, the main theme of the study is the transformation created by social media environments in the socialization process of university students.

\section{Method}

The aim of this research is to examine university students' opinions on the social media as a socialization area in terms of cultural values, nature of the information, the forms of relationship, way of expression, cultural characteristics and behavioral characteristics in the social media environment. The research is a descriptive study based on quantitative research assumptions and data was gathered from university students by the help of a questionnaire.

The questionnaire form, which was developed by the researcher based on the literature review, consists of eight sections. The aim of the first section is to collect data about students' gender, department, class, age, family income status and their habits in using social media. The following sections were prepared to learn university students opinions about aims in usage of the social media, cultural values in social media environments, the nature of the information shared in the social media environment, the forms of the relationship in social media 
environments, the way people express themselves in social media environments, the characteristics of the culture in the social media environment and the characteristics of the people in social media environments. These sections consist of a total of 48 questions consisting of response options "absolutely agree", "agree", "undecided", "disagree" and "absolutely disagree"

The data were collected from 394 students who studied at Mersin University (4 faculties, 1 college and 1 vocational college) at the beginning of the 2018-2019 academic year fall semester. The data was first encoded and loaded into the SPSS package program. The frequency and percentage descriptive statistical techniques were carried out following the research sub-problems and the opinions of the university students participating in the study on social media networks as a socialization area were examined.

\section{Findings}

$\% 49.5$ of the university students participated to the present study were female and $\% 50.5$ were male. $\% 33.5$ of the students were $16-19$ years old, $\% 25.4$ were 20 years old, $\% 14$ were 21 years old and \%26.6were 22 years of age or older. The lowest age of the university students who participated in the study was 16 and the highest age was 43.

$\% 32$ of university students 2 hours or less, \%40, 2 hours 30 minutes to 4 hours 30 minutes, \%16between 5 hours and 6 hours 30 minutes, \%11 is 7 hours and over have spent time in their environment. The minimum period of use of social media for university students was 30 minutes and the maximum duration of use was 15 hours. Daily average social media usage period of university students was 4 hours and 15 minutes.

$\% 92$ of the university students were found to use Instagram, \%91 to Watsapp, \%87 to Youtube, $\% 47$ to Twitter and $\% 23$ to Facebook. A large number of the students use Instagram and Watsapp, at least they use Facebook.

$\% 89$ of the students stated that they use social media to communicate with their friends and $\% 84$ to chat, $\% 71$ of the students stated that they use social media networks to play, have fun and spend time, $\% 80$ to learn culturally, $\% 70$ for educational purposes, $80 \%$ for video, music, picture, photo sharing, $\% 74$ to follow people and social groups. $\% 39$ of the students also stated that they use social media in order to control what their friends are doing and \%46 to express themselves.

$\% 61$ of the students stated that people in social media did not behave sincerely, \%48 of the students stated that people in social media were not helpful and \%63 of the students stated that people in social media did not have real friendship relations. $\% 46$ of the students stated that social media environments did not strengthen national values, and \%33 stated that they were undecided about this idea. Findings also have shown that $\% 60$ of the students thought that social media networks do not strengthen religious values and \%30 of them are undecided about this issue. \%54of the students think that the shared information is not mostly scientific. \%37 of the students stated that they increased their intellectual culture, $\% 11$ said they were confident about the accuracy of the information, \%54 stated that the information mostly included magazines and gossip, and \%40 said that they increased their general culture.

$\% 11$ of the students believe that social media strengthens family relations, $9 \%$ think that social media relations are a substitute for a family relationship, $\% 18$ of the students stated that friendship with social media is a true companion and $\% 38$ of them said that social media communication is as fun and enjoyable as real life. \%63 of university students think that friendships in social media are artificial, $\% 55$ prefer to make friends with people with similar views on social media, and \% 47 of them think that they like the sharing of their friends.

$\% 48$ of the students stated that they could express their thoughts, and $\% 38$ stated that they could express their feelings and thoughts as they wanted. Only $\% 15$ stated that they felt safer in social media than in social life. $\% 66$ of the students stated that they liked it when their ideas and photos on social media were liked by others, and $44 \%$ stated that they could express their problems more easily on social media. 
\%83of the students think that people are in an effort to compare themselves with others in the social media environment, while $\% 82$ believe that people are trying to show themselves as they are happy. \%86 of university students say that people are trying to prove themselves in social media and $\% 80$ of people are trying to show and reveal what they have, $\% 77$ of people think that people look at each other. The percentage of students who stated that they had encountered the content of violence in the social media shares was $\% 51$, while the rate of undecided was $\% 29 . \% 84$ of the students stated that they were exposed to advertisements that they did not want on social media. $\% 75$ of the students think that individuals do not give correct explanations about themselves, $\% 79$ of them think that people hide themselves and \% $74 \mathrm{of}$ them think that people use virtual identity and character in social media.

$\% 75$ of the students think that individuals do not give correct explanations about themselves in social media, $\% 79$ of the students think that people hide themselves and $\% 74$ of them think that people use virtual identities and characters. In addition, $\% 74$ of the students stated that unhappy and lonely people spent more time on social media.

\section{Discussion/Conclusion}

According to the findings of the research, university students think that other people do not act honestly and sincerely in social media environments and they do not have real friendship relations. University students state that information in social media is usually not scientific knowledge, it is an information based on magazines and gossip, and that the forms of relationship in social media do not replace the real family and friendship relationship. 